\title{
Extraction, Isolation and Characterization of Bioactive Compounds from Artemisia and Their Biological Significance: A Review
}

\author{
Rosemary Anibogwu ${ }^{1}$, Karl De Jesus ${ }^{1}$, Samjhana Pradhan ${ }^{2}$, Srinath Pashikanti ${ }^{1,3}$, \\ Sameena Mateen ${ }^{3}$ and Kavita Sharma ${ }^{3, * \text { (I) }}$
}

\section{check for}

updates

Citation: Anibogwu, R.; Jesus, K.D.; Pradhan, S.; Pashikanti, S.; Mateen, S.; Sharma, K. Extraction, Isolation and Characterization of Bioactive Compounds from Artemisia and Their Biological Significance: A Review. Molecules 2021, 26, 6995. https:// doi.org/10.3390/molecules26226995

Academic Editors: Gianluca Paventi, Giuseppe Rotundo, Giacinto

S. Germinara and Luisella Verotta

Received: 25 August 2021

Accepted: 16 November 2021

Published: 19 November 2021

Publisher's Note: MDPI stays neutra with regard to jurisdictional claims in published maps and institutional affiliations.

Copyright: (c) 2021 by the authors. Licensee MDPI, Basel, Switzerland This article is an open access article distributed under the terms and conditions of the Creative Commons Attribution (CC BY) license (https:// creativecommons.org/licenses/by/ $4.0 /)$.
1 Department of Chemistry, Idaho State University, Pocatello, ID 83209, USA; anibrose@isu.edu (R.A.); dejekarl@isu.edu (K.D.J.); pashsrin@isu.edu (S.P.)

2 School of Chemical Engineering, Yeungnam University, Gyeongsan 38541, Korea; samjhanapradhan313@gmail.com

3 Biomedical and Pharmaceutical Sciences, Kasiska Division of Health Sciences, College of Pharmacy, Pocatello, ID 83209, USA; sameenamateen@isu.edu

* Correspondence: kavitasharma3182@gmail.com

\begin{abstract}
Diverse medicinal plants such as those from the genus Artemisia have been employed globally for centuries by individuals belonging to different cultures. Universally, Artemisia species have been used to remedy various maladies that range from simple fevers to malaria. A survey conducted by the World Health Organization (WHO) demonstrated that $80 \%$ of the global population is highly reliant on herbal medicine for their primary healthcare. WHO recommends artemisininbased combination therapies (ACT) for the treatment of global diseases such as malaria. Artemisinin is a bioactive compound derived from Artemisia annua leaves. It is a sesquiterpene endoperoxide with potent antimalarial properties. This review strives to instill natural products to chemists and others in diverse fields with a heterogeneous set of knowledge compiled from multifaceted researchers and organizations in literature. In particular, the various Artemisia species and effective extraction, isolation, and characterization methodologies are discussed in detail. An in-depth investigation into the literature reveals that divergent species of Artemisia exhibit a vast array of biological activities such as antimalarial, antitumor, and anti-inflammatory activities. There is substantial potential for bioactive compounds from Artemisia to provide significant relief from differing human ailments, but more meticulous research in this field is needed.
\end{abstract}

Keywords: Artemisia; extraction; isolation; bioactive compounds; biological activity

\section{Introduction}

The beauty of natural products chemistry can be witnessed in the sheer diversity of its sources. Plants, animals, and microorganisms contain a vast quantity of bioactive compounds. Plants specifically present remedies for the treatment of various anthropogenic ailments in several continents around the globe such as in Asia, Africa, and South America [1]. Traditional medicine involving plants is used by $80 \%$ of the global population and serves as the primary healthcare system [2]. The role compounds derived from natural sources play in the drug discovery process can never be overemphasized. Artemisia has indiscriminately served as a treatment for maladies such as viruses, malaria, bacteria, hepatitis, fungi, cancer, and inflammation [3]. Thus, the biodiversity of nature is something that is to be cherished and upheld. Among the many appealing aspects of biodiversity, the biodiversity of nature signifies numerous untapped opportunities to discover novel plant secondary metabolites. These secondary metabolites originating from flora serve the plant by protecting it against pathogens and herbivores. The primary classes of secondary metabolites for Artemisia species are phenolic compounds, terpenoids, and alkaloids, coumarins, acetylenes, sterols, and caffeoylquinic acids [1,2]. 
With the distinctive therapeutic and medicinal properties that Artemisia L. possesses, it would be quite remiss to not discuss its taxonomic classifications to arrive at a more holistic perspective of its scope and potential. The genus, Artemisia L., is considered to be one of the largest enumerable and dispersed genera in existence [2]. It is a member of the Asteraceae family (Compositae), a sizable taxonomic classification, which encompasses approximately 1000 genera and 20,000 species [3]. Artemisia is a member of the Anthemideae tribe, which is inclusive of over 500 species; these species are predominantly located in geographic regions such as North America, Europe, and Asia [3]. The species of Artemisia are characterized by their annual, biannual, and perennial herbs or compact shrubs.

A superb advantage of the Artemisia genus is its ability to thrive and persist in nearly all habitat types. To better comprehend the primacy of Artemisia, it is worthwhile to recognize its global presence. Artemisia is indigenous to Europe, North America (United States and Canada), South America (Brazil) Southeast Asia, South Africa, and the Pacific Islands [4]. The preferred climate for this genus is arid and semi-arid. With the exception of Antarctica, Artemisia is incontrovertibly well dispersed on the global arena [5]. Its farreaching distribution allows for its unique morphology and characteristics [5]. Artemisia effortlessly adapts to a wide range of temperatures but thrives in moist soils [4]. The capability of this species to be able to adapt and survive in both warm and cool temperature environments provides a highly valuable protective mechanism against extinction. Field pictures of eight Artemisia species are present in the Figure 1.

\section{Traditional and Current Uses of Artemisia Species}

Artemisia absinthium L. is typically referred to as wormwood and is a perennial plant that is dispersed and distinguishable across parts of Siberia and Europe [3]. It produces vibrant yellow flowers and possesses a wide array of uses. For instance, its antiparasitic properties allow for the treatment of anorexia and indigestion [3]. Moreover, the aerial parts of this shrub can serve as a component in various gastric herbal concoctions, intoxicating beverages, and dietary supplements [3]. In the ethnopharmacological sphere, Artemisia absinthium L. has functioned to restore diminished mental performance, to alleviate liver inflammation, and to enhance memory [2]. The antioxidant activity of the aerial components of $A$. absinthium has been evaluated by measuring the free-radical scavenging activity of $A$. absinthium extracts to remove reactive hydroxyl radicals and stable 2,2-diphenyl-1-picrylhydrazyl (DPPH) free radical "during the Fenton reaction trapped by 5,5-dimethyl-1-pyrroline-N-oxide", along with the use of electron spin spectroscopy [2]. Prior research has conveyed that crude ethanol and aqueous extracts of the aerial parts of $A$. absinthium display anthelmintic activity when juxtaposed to the effectiveness of albendazole "against the gastrointestinal nematodes of sheep" [2].

Artemisia annua L. is commonly known as "huanghuahao" (yellow flower Artemisia) and it distributes from north to south to almost all parts of China [7]. It is also native to Tanzania, Kenya, India, Romania, Inner Mongolia and Hebei provinces and Vietnam [8]. In Chinese culture, $A$. annua has been utilized to address fever and chills since the second century B.C. [3,7]. This plant has been introduced to disparate parts of the world. For example, in Africa, A. annua is cultivated and employed in tea form to treat malaria [3]. A clandestine research project known as Project 523 was postulated in a meeting on 23 May 1967, amid the Vietnam War [7]. Evidently, the death toll experienced by North Vietnamese soldiers during battle was eclipsed by the number of soldiers that met their premature demise by malaria. Thus, the search began to discover antimalarial compounds for both the Chinese citizens and the North Vietnamese soldiers. In 1972, a year that marked a turning point for the health of a nation, artemisinin was extracted and recognized for its highly efficacious anti-malarial activity from $A$. annua [7]. Initially, the potency of this anti-malarial compound, artemisinin, was trivialized by the Western world [7]. Nonetheless, artemisinin repeatedly demonstrated its effectiveness against schistosomiasis and malaria [7]. In addition to A. annua's antimalarial efficacy, it has been proposed that A. annua can also effectively combat human immunodeficiency virus (HIV) [9]. Therefore, 
more recent research investigations are involved in determining its antiviral activity against HIV [9]. This is especially pertinent because HIV is a prolific global disease.

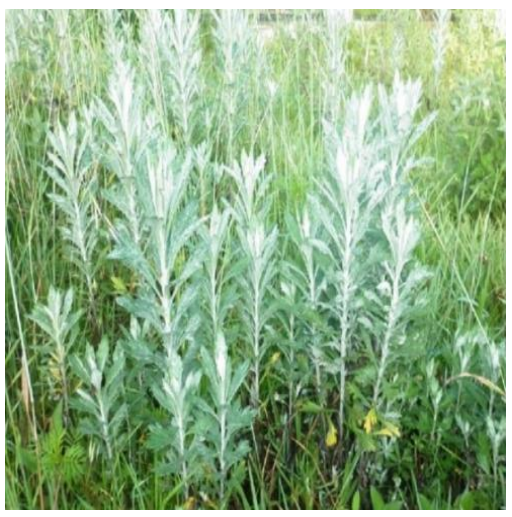

(a)

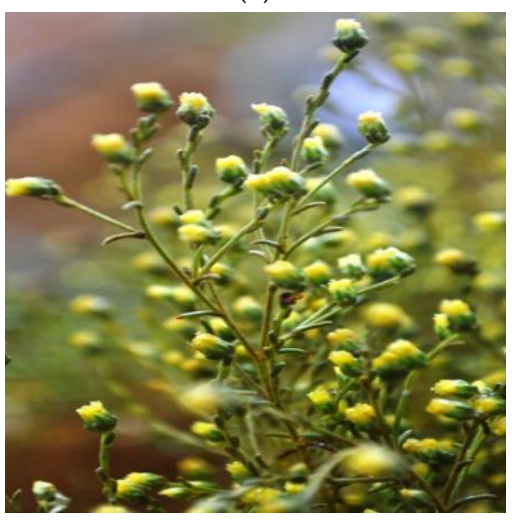

(d)

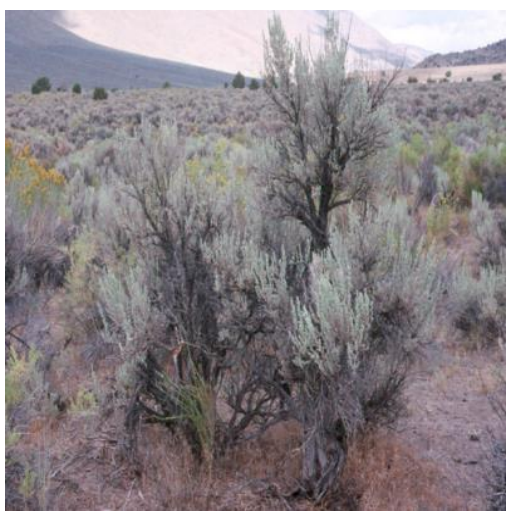

(g)

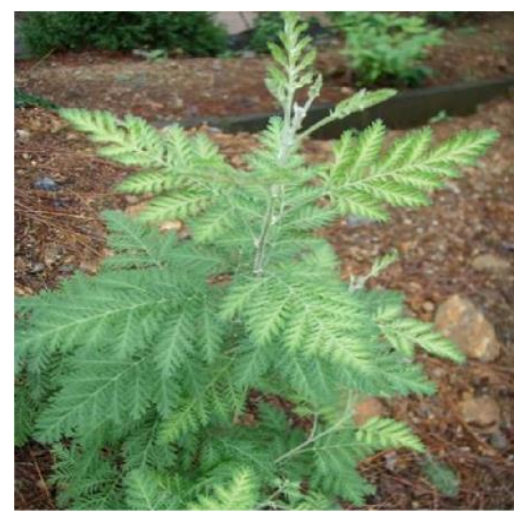

(b)

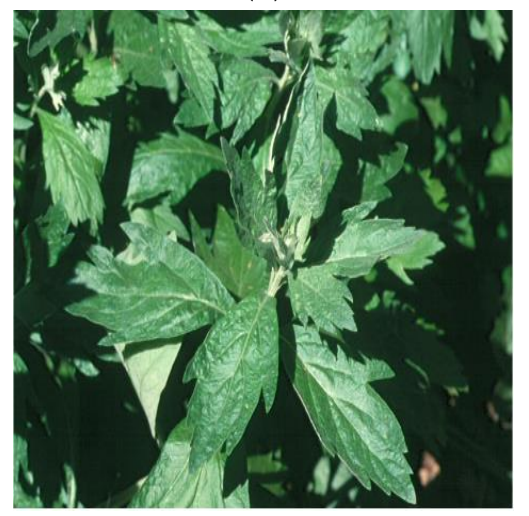

(e)

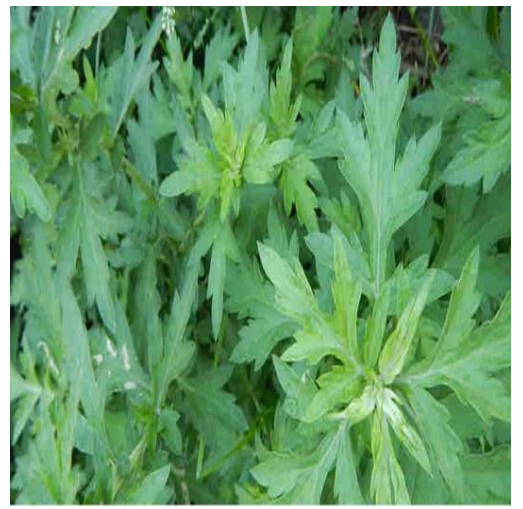

(h)

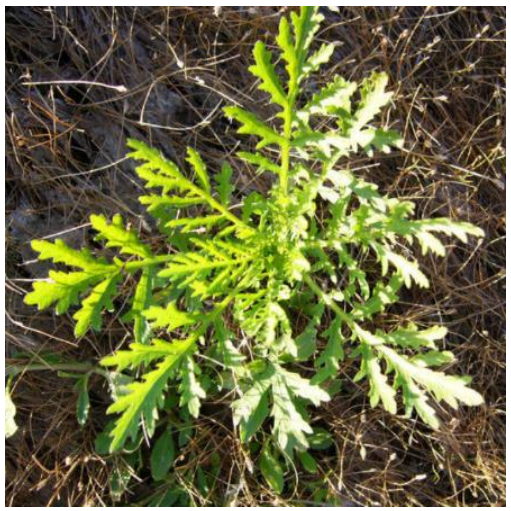

(c)

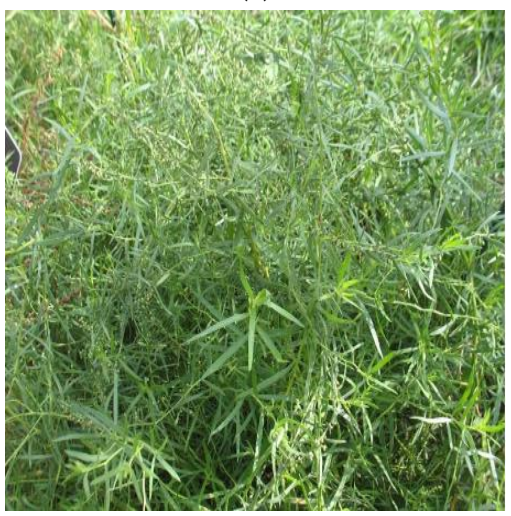

(f)

Figure 1. Field pictures of eight Artemisia species [6]: (a) Artemisia absinthium, (b) Artemisia annua, (c) Artemisia biennis, (d) Artemisia campestris, (e) Artemisia douglasiana, (f) Artemisia dracunculus, (g) Artemisia tridentata, and (h) Artemisia vulgaris.

Artemisia biennis is typically known as biennial wormwood and is an annual or biennial species naturally present in western North America [10]. The spreading of $A$. biennis throughout North America occurred as a result of anthropogenic activities such as transportation [10]. The proliferation of A. biennis in agricultural lands can be ascribed to a forbearance of some classes of herbicides, shift in annual growth patterns, crop diversification, and a rise in reduced tillage systems usage $[10,11]$. A. biennis thrives in highly disturbed habitats and can effortlessly outperform species native to a certain habitat. In this fashion, biennis is considered an invasive species. Although this herb can be quite a 
quandary in certain regions, it does possess some beneficial uses. This species commonly functions as an antiseptic in folk remedies and also used for cooking purposes [9]. Furthermore, A. biennis has been employed by the indigenous people of North America as ointments and medicinal cleansers for the treatment of wounds, sores, and chest infections [3]. In Iran, the essential oil of this herb is primarily composed of camphor [12]. However, in Western Canada, the most copious volatile compound in the aerial portions of $A$. biennis is $€-\beta$-farnesene [8,12]. Mojarrab et al. (2016) carried out an investigation that sought to determine the efficacy of fractions derived from $A$. biennis hydroethanolic extract to grant "cytoprotection against oxidative stress and apoptosis induced by doxorubicin (DOX) in rat pheochromocytoma cell line (PC12)" [8,12]. This investigation corroborated that oxidative stress injury as well as "apoptosis induced by DOX in the PC12 cells" was attenuated by the hydroethanolic extract of $A$. biennis $[8,12]$.

Artemisia campestris L. is frequently referred to as tgouft and is a faintly fragrant perennial herb widely distributed in the south of Tunisia, North Africa, North America, and Eurasia $[3,10,13]$. The leaves and flowers of $A$. campestris were conventionally implemented for the treatment of high cholesterol levels, obesity, hypoglycemia, and venin [13]. Innumerable studies attest to $A$. campestris's bioactivity. The biological activities of this plant include allelopathic, anthelmintic, antimicrobial, antidiabetic, hepatoprotective, insecticidal, nephroprotective, antivenomous, antiulcer, antioxidant, and antitumor [13]. The study conducted by Ivanescu et al. (2018) on Artemisia campestris from Romania divulged novel bioactive compounds such as acacetin, casticin, eupatorin, stigmasterol, $\alpha$-sitosterol, gentisic acid, and campesterol through various biological assays and LC-MS [10,13].

Artemisia douglasiana L. is commonly referred to as California mugwort and is a perennial herb native to the Western United States, particularly in northern California, Washington, and Oregon [9]. In Cuyo, a region in which A. douglasiana is nonnative, it is cultivated and used in traditional medicine [3]. The natives of Cuyo refer to A. douglasiana as "matico"; it is employed for the treatment of gastrointestinal disorders and peptic ulcers [3]. Furthermore, Artemisia douglasiana serves as a tonic to remedy nervous disorders and to stimulate menstruation [9]. The essential oil of $A$. douglasiana has been utilized for aromatherapy, relieving tense muscles, mollifying mental anguish, and inhalation to enhance mental clarity [9]. According to Setzer et al. (2004), the leaf oil from A. douglasiana analyzed by GC-MS revealed the prime components of the oil to be $29 \%$ camphor, $26 \%$ Artemisia ketone, 13\% Artemisia alcohol, 10\% alpha-thujone, 8\% 1,8-cineole, and 15\% hexanal [12,14].

Artemisia dracunculus L. is also known as "tarragon" and is considered a perennial herb widely distributed in western North America, eastern and central Europe, and a majority of temperate Asia [15]. A. dracunculus is also cultivated in India, Russia, Iran, and Ukraine [16]. This herb possesses an extensive background in culinary practices. In America, tarragon is used in seafood, chicken, eggs, tartar sauce, and vinegar [15]. In France, tarragon is used to flavor French Dijon mustard, sour cream, eggs, and mayonnaise [15]. Due to its diverse and expansive health promoting properties, it typically functions as herbal medicine [3]. For instance, extracts of $A$. dracunculus have been made use of by Himalayan natives to pacify toothache, relieve fever, and to remedy gastrointestinal issues [9]. Tarragon possesses phenomenal antibiotic activity; in Tibetan medicine, this plant is used to treat chronic bronchitis, pulmonary tuberculosis, and pneumonia [16]. Native American Chippewa tribe utilized the roots of tarragon to mitigate superfluous flow during the menstruation period and to assist in strenuous labor [15]. The dominant essential oil components of A. dracunculus consist of coumarins, flavonoids, and phenolic acids [15].

Artemisia tridentata Nutt. is informally known as "basin big sagebrush" and is a perennial shrub that possesses a vast range of distribution [9]. This shrub is native to the semiarid Southwestern United States [17]. Artemisia tridentata encompasses the following subspecies: tridentata, vaseyana, wyomingensis, rupicola, xericansis, scopulorum, and thermopola. A. tridentata serves as a consequential habitat for a great variety of fauna [9,14]. Big sagebrush boasts an assortment of uses. Native Americans utilize this shrub to remedy flu and colds [17]. Historically, A. tridentata has been employed for the alleviation of 
fevers, poisoning, and gastrointestinal issues. Although basin big sagebrush is frequently lauded for its appreciable chemotherapeutic and bactericidal activities, it is an efficacious aeroallergen and liable to cause dermatitis [17]. The most salient compounds present in A. tridentata include sesquiterpenes, flavonoids, monoterpenes, and coumarins [17].

Artemisia vulgaris L. is quite a significant medicinal plant species that contains volatile oils. This plant is known by many endearing and unique names, but perhaps the most common being Mugwort [1]. Interest in Artemisia is specifically related to its phenomenal biological and chemical biodiversity along with the discovery of antimalarial drug artemisinin. Artemisia vulgaris has a prominent history distinguished by its use as a medicinal plant for the alleviation of human afflictions globally [1]. Artemisia vulgaris possesses a diverse array of medicinal properties inclusive of anti-septic, anti-inflammatory, anti-spasmodic, anti-hypertensive, hepatoprotective, anti-oxidant, and anti-tumoral [1] The secondary metabolites in this plant are responsible for these valuable properties. Some of the more prominent classes of secondary metabolites are flavonoids, sesquiterpene lactones, phenolic acids, acetylenes, and coumarins [1]. Pharmacological and phytochemical investigations have confirmed the medicinal capability of bioactive compounds [1]. Due to the versatility of A. vulgaris, demand continues to soar in an unsustainable fashion.

A great variety of flavonoids has been isolated from Artemisia vulgaris; the primary classes are flavones, flavone glycosides, flavanols, and flavonol glycosides [5]. In the case of the flavones class: tricine, apigenin, eupafolin, luteolin, diosmetin, jaceosidine, and chrysoeriol were extracted. For flavone glycosides, vitexin and luteolin 7-glucoside were extracted. Flavones eluted include eriodictyol and homoeriodictyol. As for the flavonols class, only isorhamnetin was isolated. The compounds within the class of flavonol glycosides that were extracted includes kaempferol 3-glucoside, rutin, kaempferol 3-rhamnoside, quercitrin, kaempferol 3-rutinoside, and quercetin 3-galactoside [5]. Luteolin and eriodictyol were determined to be the most prominent compounds isolated from vulgaris [18].

Phytonutrients such as fruits and vegetables contain fantastic pharmacological properties; pharmacological properties such as anti-inflammatory, antioxidant, and anti-carcinogenic reside within certain fruits and vegetables [19]. For instance, Eriodictyol, a flavanone, is present in citrus fruits. Eriodictyol possesses anti-inflammatory properties which can garner tremendous aid for the care of diabetic retinopathy [20]. Luteolin is commonplace in the food industry and is notably utilized in oregano, peppermint, olive oil, and plantbased food. Luteolin is a bioactive compound replete with a wonderful array of biological properties such as antioxidant, anticancer, antimicrobial, and anti-inflammatory (in vivo and in vitro) [21].

A. vulgaris is not a significant source of artemisinin when compared to its presence in other Artemisia species such as Artemisia annua [22]. Essential oils of A. vulgaris comprise $\alpha$-thujone, $\alpha$-pinen, $\beta$-caryophyllene, camphor, 1,8-cineole, camphene, and germacrene [5]. The essential oils that were isolated appeared to assume a green hue in conjunction with a pervasive camphoraceous scent and a bitter-sweet taste. These characteristics can be imputed to the presence of an appreciable quantity of oxygenated monoterpenes and sesquiterpenes in the oil of the stem. The oxygenated monoterpene and sesquiterpene content present in the extracted essential oils of $A$. vulgaris have been evaluated: monoterpenes (camphor [17.3\%], alpha-thujone [10.7\%], and 1,8-cineole [5.1\%]) and sesquiterpene derivatives (gamma-muurolene [9,0\%] and beta-caryophyllene [5.8\%]) [23].

The presence of essential oils in A. vulgaris are reliant on aspects such as environmental conditions, geographic derivation, and stages of plant development [5]. Moreover, the distinct oils contained in specific plant parts were monitored in varied biological stages to gauge other facets that played noteworthy roles in the quantity and quality of the essential oils. Unsurprisingly, stress factors and population genetics also contribute to the quantitative and qualitative compositions of A. vulgaris in dissimilar regions [5]. As evidenced by the GCMS analysis, essential oils in Mugwort from Morocco were found to be far more profuse in camphor and isothujone/thujone ratio when compared to Mugwort from 
Iran which was abundant in $\alpha$ and $\beta$-pinene [24,25]. Furthermore, in comparing essential oils from Italy and India, it has been reported that Mugwort from Italy is significantly composed of camphor $(47 \%)$ or camphor $(2-20 \%)$ with myrcene $(9-70 \%)$, while vulgaris from India is principally composed of camphor (38.7\%) and isoborneol $(8.2 \%)[26,27]$.

According to the literature, camphor is one of the most prevalent essential oils in A. vulgaris, even in dissimilar regions globally. The increase in camphor concentration has been determined to accumulate in the following order: seeding stage, flowering, buds, and vegetative [5]. In 2006, the disparities in the chemical composition of the essential oils in the root and aerial parts of $A$. vulgaris were confirmed to demystify the influence plant parts and storage had on the composition and yield of essential oils. The essential oils extracted from the aerial parts of the plant divulged a copious amount of 1,8-cineole (28.9\%), sabinene (13.7\%), $\beta$ thujone (13.5\%), and $\beta$-caryophyllene oxide (6.5\%) [28]. Conversely, the oils of primacy isolated from the root were neryl 2-methylbutanoate (13.2\%), $\beta$-eudesmol $(10.0 \%)$, and bornyl 3-methylbutanoate (8.4\%) [28]. This indicates that the location in which essential oils are extracted from a plant is consequential.

The utility of $A$. vulgaris in various geographic locations and cultures appears endless. Mugwort has been known to possess an array of therapeutic properties and applications; it has conventionally been employed to remedy indigestion, liver disorders, and stomach ulcers [29]. Furthermore, it has been reported that the entire plant can alleviate diabetes, insomnia and stress, depression, anxiety, epilepsy, and worm infestation. It can also be used to stimulate delayed or inconsistent menstruation [29]. The leaves and stem of Mugwort have served as a uterine stimulant and digestive tonic. Alternatively, to season fish and meat, the leaves and buds of Mugwort can be quite useful in preparing a rather savory meal. For instance, in Asia, this herb has reportedly been utilized to add flavor to tea and traditional cuisines [26].

The antioxidant capability of $A$. vulgaris has been explored by Sharmila and Padma (2014) using methanol extract in chick embryos exposed to oxidative stress [30]. This demonstrated that in the presence of $A$. vulgaris, the antioxidant activity of primary cells that were placed under oxidative stress were enhanced [30]. In another study carried out by Haniya and Padma (2014), when exposed to the free radical agents such as DPPH, ABTS, hydrogen peroxide, superoxide, hydroxyl radicals, and nitric oxide, the solvent extract that demonstrated the optimal scavenging effects was the methanol extract [31]. This corroborated the antioxidant strength of A. vulgaris leaf extract.

In an experiment conducted by Afsar et al. (2013), the anti-inflammatory activity of Mugwort was analyzed with the cotton pellet granuloma method. Once cotton pellets were surgically implanted into the groin of rats, methanol leaf extracts were delivered at doses of 200 and $400 \mathrm{mg} / \mathrm{Kg}$ body weight [5,32]. It was determined that at $400 \mathrm{mg} / \mathrm{Kg}$, there was a $64.0 \%$ inhibition in weight of dry cotton pellets and $55.3 \%$ inhibition in weight of wet cotton pellets in comparison to the control $[5,32]$. This dose-dependent anti-inflammatory characteristic can be attributed to flavonoids present in A. vulgaris.

\section{Extraction, Isolation, Characterization}

The aim of this review is to address the process involved in order to obtain pure compounds from crude plant extracts, which includes the combination of extraction/sample preparation tools and analytical techniques, for isolating and characterizing bioactive compounds from plants, as potential lead compounds in the drug discovery process. A flowchart of stages involved in extraction, isolation and characterization of bioactive compounds from Artemisia is present in Figure 2. 


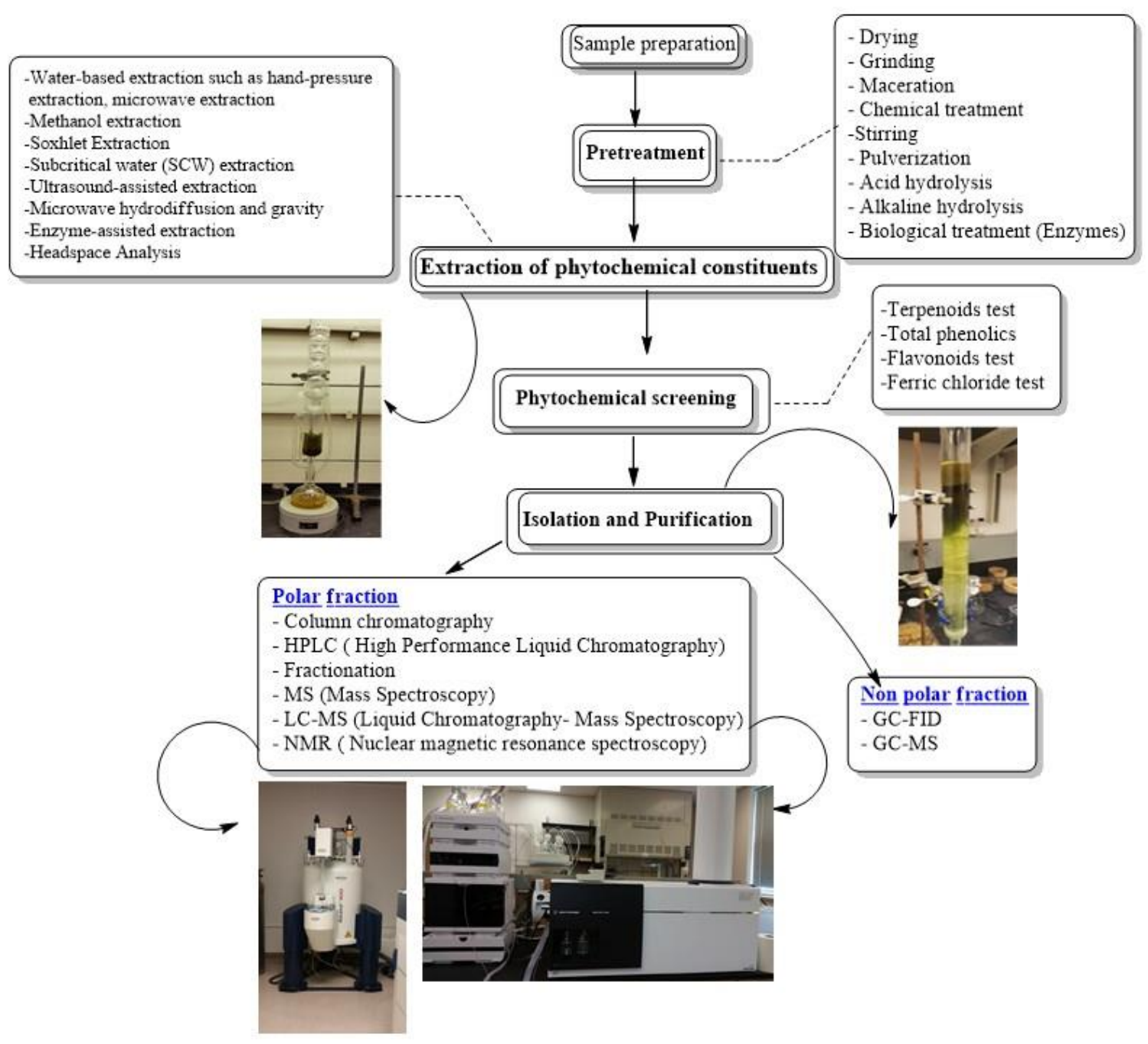

Figure 2. Flowchart of stages involved in extraction, isolation and characterization of bioactive compounds from Artemisia.

\subsection{Extraction Techniques}

Fauna and flora possess an extensive array of bioactive compounds that can be applied to the enhancement of human wellbeing. However, the extraction of these bioactive compounds by various research groups can be carried out in a more sustainable fashion that can preserve the abundance and richness of the species used in research. Conventional extraction methodologies are entrenched in the employment of vast quantities of organic solvents only to result in less than satisfying extraction yields [33]. Thus, it is imperative and worthwhile for green extraction techniques to be explored. Such techniques prioritize the avoidance of toxic solvents and the increase of extraction yields with minimal energy expenditure. Currently, supercritical fluid extraction (SFE) and pressurized liquid extraction (PLE) are ubiquitous high-pressure techniques for the elution of bioactive compounds from natural sources [33]. These techniques possess considerably high extraction efficiencies [33]. Some of the extraction technique used for the extraction of bioactive compound of Artemisia species has been mentioned in Table 1 .

Supercritical fluid extraction (SFE) makes use of a specific solvent under temperatures and pressures beyond its critical point. Under such conditions, the fluid undergoes "physicochemical changes" that impart alterations to its solvent properties [33]. Consequently, no phase separation is observed, and a homogenous supercritical fluid is obtained. This enables supercritical fluids to achieve viscosities akin to gaseous substances while simultaneously retaining densities homologous to liquid substances. These characteristics, 
in conjunction with others, are what distinguish supercritical fluids from more orthodox solvents found under ambient parameters.

The SFE technique can be utilized for the extraction of bioactives from a great variety of natural resources [33]. Carbon dioxide is perhaps the most prominent supercritical fluid made use of for bioactive extraction [33]. The ubiquitous use of supercritical $\mathrm{CO}_{2}\left(\mathrm{sc}-\mathrm{CO}_{2}\right)$ can be ascribed to its affordability, safeness, moderate critical temperature and pressure ( $31.2{ }^{\circ} \mathrm{C}$ and 73.8 bar, respectively) that is effortlessly attainable, and FDA designation of Generally Recognized As Safe (GRAS) for the food industry [33]. Moreover, $\mathrm{CO}_{2}$ is considered to be a by-product of various industrial processes [33]. Therefore, the use of $\mathrm{CO}_{2}$ is considered environmentally friendly since it is being reused. Another compelling facet of $\mathrm{CO}_{2}$ that makes it an appealing solvent alternative is that its gaseous phase can be maintained at room temperature [33]. This allows for direct and effortless evaporation of $\mathrm{CO}_{2}$ from the extract upon the completion of the extraction procedure [33]. Temperature and pressure play an appreciable role in the extraction process since their unique combinations inherently determine the density of sc- $\mathrm{CO}_{2}$ and thereby the capability to selectively elute certain substances from the extract matrix [33]. As with most systems, there does exist a caveat for this technique. The polarity of sc- $\mathrm{CO}_{2}$ is fairly low, which can be interpreted as polar bioactive compounds being neglected in the extraction process [33]. However, with the use of a modifier or a co-solvent such as ethanol in small quantities, the polarity of sc- $-\mathrm{CO}_{2}$ can be enhanced [33]. Thus, expanding the range of bioactive compounds that can be extracted.

The other illustrious high-pressure green technique is called pressurized liquid extraction (PLE). Pressurized liquid extraction is also referred to as accelerated solvent extraction (ASE) or pressurized fluid extraction (PFE) [33]. PLE is a technique characterized by the employment of suitable pressures to sustain the solvent in its liquid phase and high temperatures that lay below the critical point [33]. When juxtaposed to more conventional methods, the merits of PLE can clearly be appreciated. For instance, a smaller amount of solvent is needed to carry out the technique. As a result, the efficiency of extraction is enhanced due to a better mass transfer rate. Under elevated temperature conditions, solvent solubility is improved while viscosity decreases; this aids in matrix penetration and mass transfer [33]. Doubtlessly, pressure and temperature are consequential parameters to be considered when performing PLE. However, while pressure is a significant parameter, increasing pressure beyond the point necessary to maintain the solvent in its liquid state has a negligible impact on the extraction process [33]. Instead, time would be better spent on selecting a solvent that is consistent with the nature of the desired compounds.

The considerably low concentrations of bioactive compounds in Artemisia species presents a profound challenge that can sometimes derail the progress of their analysis. The extraction of bioactive compounds free of interferents using conventional methods is nearly unattainable. Hydrophilic deep eutectic solvents (DESs) have captured the attention of many and are considered green alternatives for the efficient extraction of bioactive compounds [34]. In an investigation carried out by Jun Cao et al. (2017), the merits of DESs are illuminated and compelling incentives for the use of DESs are discussed. A considerable amount of DESs is typically composed of two or more non-noxious, nonflammable, biodegradable, and inexpensive components that interact with one another via hydrogen bonding [34]. Moreover, deep eutectic solvents possess a wide range of hydrogen bond donors (HBDs) and hydrogen bond acceptors (HBAs) which make them applicable in a wide array of fields due to their minimal toxicity, simple preparation, biodegradability, and unique properties [34].

The fundamental intent of this study was to evaluate whether DESs could improve the concentration of artemisinin extracted from Artemisia annua, thereby improving the extraction efficiency. To achieve this end, a series of "screening and tailoring" was carried out to determine which DES would produce the greatest extraction yield ${ }^{30}$. Subsequently, a hydrophobic DES known as N81Cl-NBA was chosen as the solvent for extraction due to its high extraction yield. N81Cl-NBA was prepared from methyl trioctyl ammonium chloride 
and 1-butanol using a molar ratio of 1:4 [34]. N81Cl-NBA-based ultrasound-assisted extraction was employed, and the components influencing extraction yield were statistically optimized [34]. Jun Cao et al. (2017) concluded that N81Cl-NBA-based ultrasound-assisted extraction along with "macroporous resin separation" demonstrated a higher extraction efficiency and an artemisinin recovery yield of $85.65 \%$ was achieved [34]. Compared to $60-80 \%$ yield of artemisinin using conventional organic solvents such as petroleum ether, this is a pleasing improvement [34]. This investigation was able to demonstrate that DESs are "designer solvents" that can be utilized as green extraction solvents for the extraction of bioactive compounds from plant material [34].

Table 1. Bioactive compound extraction techniques for Artemisia species.

\begin{tabular}{|c|c|c|c|c|c|c|c|}
\hline $\begin{array}{l}\text { Species } \\
\text { Name }\end{array}$ & Origin & Method & Plant Part & $\begin{array}{l}\text { Solvent } \\
\text { System }\end{array}$ & $\begin{array}{l}\text { Bioactive } \\
\text { Constituent }\end{array}$ & $\begin{array}{l}\text { Percent } \\
\text { Yield (\%) }\end{array}$ & Reference \\
\hline $\begin{array}{l}\text { Artemisia } \\
\text { annua }\end{array}$ & $\begin{array}{l}\text { Astore, Northern } \\
\text { Areas Pakistan }\end{array}$ & Sonication & Flowers & $\begin{array}{l}5 \mathrm{~mL} \text { HPLC } \\
\text { grade toluene }\end{array}$ & Artemisinin & $0.42 \pm 0.03 \%$ & [35] \\
\hline $\begin{array}{l}\text { Artemisia } \\
\text { annua }\end{array}$ & $\begin{array}{l}\text { Astore, Northern } \\
\text { Areas Pakistan }\end{array}$ & Sonication & Leaves & $\begin{array}{l}5 \mathrm{~mL} \text { HPLC } \\
\text { grade toluene }\end{array}$ & Artemisinin & $0.44 \pm 0.03 \%$ & [35] \\
\hline $\begin{array}{l}\text { Artemisia } \\
\text { annua }\end{array}$ & $\begin{array}{l}\text { Astore, Northern } \\
\text { Area Pakistan }\end{array}$ & Sonication & Stems & $\begin{array}{l}5 \mathrm{~mL} \text { HPLC } \\
\text { grade toluene }\end{array}$ & Artemisinin & $0.8 \pm 0 \%$ & [35] \\
\hline $\begin{array}{c}\text { Artemisia } \\
\text { dracunculus } \\
\text { var } \\
\text { dracunculus }\end{array}$ & $\begin{array}{c}\text { Abbass Pur, Azad } \\
\text { Kashmir } \\
\text { Pakistan }\end{array}$ & Sonication & Leaves & $\begin{array}{l}5 \mathrm{~mL} \text { HPLC } \\
\text { grade toluene }\end{array}$ & Artemisinin & $0.27 \pm 0 \%$ & [35] \\
\hline $\begin{array}{c}\text { Artemisia } \\
\text { dracunculus } \\
\text { var } \\
\text { dracunculus }\end{array}$ & $\begin{array}{c}\text { Abbass Pur, Azad } \\
\text { Kashmir } \\
\text { Pakistan }\end{array}$ & Sonication & Stems & $\begin{array}{l}5 \mathrm{~mL} \text { HPLC } \\
\text { grade toluene }\end{array}$ & Artemisinin & $0.12 \pm 0.01 \%$ & [35] \\
\hline $\begin{array}{l}\text { Artemisia } \\
\text { parviflora }\end{array}$ & $\begin{array}{c}\text { Rawalakot, Azad } \\
\text { Kashmir } \\
\text { Pakistan }\end{array}$ & Sonication & Stems & $\begin{array}{l}5 \mathrm{~mL} \text { HPLC } \\
\text { grade toluene }\end{array}$ & Artemisinin & $0.8 \pm 0 \%$ & [35] \\
\hline $\begin{array}{c}\text { Artemisia } \\
\text { moorcroftiana }\end{array}$ & $\begin{array}{c}\text { Kalam, Swat } \\
\text { Pakistan }\end{array}$ & Sonication & Stems & $\begin{array}{l}5 \mathrm{~mL} \text { HPLC } \\
\text { grade toluene }\end{array}$ & Artemisinin & $0.8 \pm 0 \%$ & [35] \\
\hline $\begin{array}{l}\text { Artemisia } \\
\text { sieversiana }\end{array}$ & $\begin{array}{c}\text { Soost, Northern } \\
\text { Areas } \\
\text { Pakistan }\end{array}$ & Sonication & Roots & $\begin{array}{l}5 \mathrm{~mL} \text { HPLC } \\
\text { grade toluene }\end{array}$ & Artemisinin & $0.04 \pm 0 \%$ & [35] \\
\hline $\begin{array}{l}\text { Artemisia } \\
\text { sieversiana }\end{array}$ & $\begin{array}{c}\text { Soost, Northern } \\
\text { Areas } \\
\text { Pakistan }\end{array}$ & Sonication & Stems & $\begin{array}{l}5 \mathrm{~mL} \text { HPLC } \\
\text { grade toluene }\end{array}$ & Artemisinin & $0.8 \pm 0 \%$ & [35] \\
\hline $\begin{array}{c}\text { Artemisia } \\
\text { moorcroftiana }\end{array}$ & $\begin{array}{l}\text { Kalam, Swat } \\
\text { Pakistan }\end{array}$ & Sonication & Stems & $\begin{array}{l}5 \text { mL HPLC } \\
\text { grade toluene }\end{array}$ & Artemisinin & $0.8 \pm 0 \%$ & [35] \\
\hline $\begin{array}{l}\text { Artemisia } \\
\text { vestita }\end{array}$ & Galyat, Pakistan & Sonication & Roots & $\begin{array}{l}5 \mathrm{~mL} \text { HPLC } \\
\text { grade toluene }\end{array}$ & Artemisinin & $0.04 \pm 0 \%$ & [35] \\
\hline $\begin{array}{l}\text { Artemisia } \\
\text { vulgaris }\end{array}$ & $\begin{array}{l}\text { Kalam, Swat } \\
\text { Pakistan }\end{array}$ & Sonication & Flowers/leave & $\begin{array}{l}5 \mathrm{~mL} \text { HPLC } \\
\text { grade toluene }\end{array}$ & Artemisinin & $0.05-0.15 \%$ & [35] \\
\hline $\begin{array}{l}\text { Artemisia } \\
\text { vulgaris }\end{array}$ & - & $\begin{array}{l}\text { silica gel } \\
\text { column chro- } \\
\text { matography } \\
\text { using } \\
\text { gradient } \\
\text { elution }\end{array}$ & Leaves & $\begin{array}{l}\text { Ethyl acetate } \\
\text { and } \\
\text { dichloromethane }\end{array}$ & $\begin{array}{l}\text { Yomogin and } \\
\text { 1,2,3,4- } \\
\text { diepoxy- } \\
\text { 11(13) } \\
\text { eudesmen- } \\
\text { 12,8-olide }\end{array}$ & - & [36] \\
\hline $\begin{array}{c}\text { Artemisia } \\
\text { douglassiana }\end{array}$ & - & $\begin{array}{l}\text { Liquid-liquid } \\
\text { extraction }\end{array}$ & Aerial parts & $\begin{array}{c}\text { Ethyl acetate- } \\
\text { hexane } \\
{[1: 9]}\end{array}$ & Dehydroleucodine & - & [36] \\
\hline
\end{tabular}


Table 1. Cont.

\begin{tabular}{|c|c|c|c|c|c|c|c|}
\hline $\begin{array}{l}\text { Species } \\
\text { Name }\end{array}$ & Origin & Method & Plant Part & $\begin{array}{l}\text { Solvent } \\
\text { System }\end{array}$ & $\begin{array}{c}\text { Bioactive } \\
\text { Constituent }\end{array}$ & $\begin{array}{l}\text { Percent } \\
\text { Yield (\%) }\end{array}$ & Reference \\
\hline $\begin{array}{c}\text { Artemisia } \\
\text { douglassiana }\end{array}$ & - & $\begin{array}{l}\text { Liquid-liquid } \\
\text { extraction }\end{array}$ & Aerial parts & $\begin{array}{l}\text { Silica gel } \\
\text { with } \\
\text { hexane-ethyl } \\
\text { acetate } \\
\text { mixtures }\end{array}$ & $\begin{array}{l}\text { Dehydroparishin- } \\
\text { B }\end{array}$ & - & [36] \\
\hline $\begin{array}{l}\text { Artemisia } \\
\text { diffusa }\end{array}$ & - & Maceration & - & $\begin{array}{c}\mathrm{n}- \\
\text { hexane/ethyl } \\
\text { ac- } \\
\text { etate/methanol } \\
{[1: 1: 1]}\end{array}$ & Tehranolide & - & [36] \\
\hline $\begin{array}{l}\text { Artemisia } \\
\text { princeps }\end{array}$ & - & $\begin{array}{l}\text { Liquid-liquid } \\
\text { extraction }\end{array}$ & Aerial parts & $\begin{array}{l}\text { Dichloromethane } \\
\text { fraction } \\
\text { column chro- } \\
\text { matography } \\
\text { over silica gel } \\
\text { using } \\
\text { gradient } \\
\text { elution of } \\
\text { methanol and } \\
\text { dichloromethane }\end{array}$ & Yomogin & - & [36] \\
\hline $\begin{array}{c}\text { Artemisia } \\
\text { ludoviciana }\end{array}$ & - & $\begin{array}{l}\text { Column chro- } \\
\text { matography }\end{array}$ & Aerial parts & $\begin{array}{l}\text { phase chro- } \\
\text { matographed } \\
\text { repeatedly on } \\
\text { normal- } \\
\text { phase silica } \\
\text { gel with ethyl } \\
\text { acetate and } \\
\text { hexane }\end{array}$ & $\begin{array}{c}\text { Guaianolide } \\
\text { ludartin }\end{array}$ & - & [36] \\
\hline $\begin{array}{c}\text { Artemisia } \\
\text { caerulescens } \\
\text { ssp. cretacea }\end{array}$ & - & $\begin{array}{l}\text { Concentrated } \\
\text { extract is } \\
\text { extracted } \\
\text { with boiling } \\
\text { water. } \\
\text { Aqueous } \\
\text { solutions are } \\
\text { extracted } \\
\text { with } \\
\text { chloroform }\end{array}$ & Flowers & $\begin{array}{l}\text { Aluminum } \\
\text { oxide column } \\
\text { with } 5 \% \\
\text { methanol in } \\
\text { chloroform }\end{array}$ & Santonin & - & [36] \\
\hline
\end{tabular}

\subsection{Isolation Techniques: $T L$}

Typically, plant extracts are composed of a mixture of bioactive constituents that need to be isolated for the characterization process [37]. Thin layer chromatography (TLC) is a commonplace technique for the separation of mixtures [37]. TLC analysis is a straightforward, efficient, and inexpensive method that provides the researcher with immediate results on the quantity of the components present in the mixture [38]. The performance of a TLC analysis can also be employed to corroborate the identity of a compound in a mixture by comparing the retention factor $\left(R_{f}\right)$ of the compound in the mixture with a known compound [38]. Subsequently, the components of the mixture on the TLC plate can be visualized with the use of a UV lamp [37].

In a study conducted by Mohammad Bagher Pasha Zanousi (2012), Agrobacterium rhizogenes promoted the formation of hairy roots in an "Iranian clone of Artemisia annua" to evaluate the production of artemisinin in the newly formed hairy roots by TLC analysis [38]. To begin the TLC analysis, the artemisinin standard was dissolved in HPLC grade acetonitrile to produce a $1000 \mathrm{ppm}$ concentration of artemisinin [38]. The anhydrous 
extracts were placed in $1 \mathrm{~mL}$ of acetonitrile. Additionally, a micropipette was used to spot the silica gel TLC plate. The TLC plate was subsequently placed in a glass TLC chamber containing a solvent system of acetone/hexane with a 3:10 molar ratio [38]. The plate was developed to a height of $3 \mathrm{~cm}$ and left to air dry at room temperature [38]. The dry TLC plate was visualized in an iodine tank [38]. Finally, artemisinin was identified by comparing the color intensity of the artemisinin standard to the other extracts [38].

The TLC analysis provided insight into the concentration of artemisinin in the standard and various root types evaluated. The artemisinin standard (1000 ppm) contained the highest artemisinin concentration since it was the darkest spot on the TLC plate. In comparing the color intensity of the hairy roots extract and the control roots extract on the TLC plate, it was determined that the hairy roots extract possessed a higher concentration of artemisinin than the control roots. In essence, this research confirmed that inducing the formation of hairy roots in the leaves of $A$. annua proved effective for the increased production of artemisinin.

High-performance liquid chromatography (HPLC) is a ubiquitous technique utilized for the isolation of secondary metabolites. Natural products such as secondary metabolites are typically isolated after the examination of the crude extract in a biological assay; this is performed to achieve a more holistic characterization of the bioactive constituents [37]. The meager quantities of bioactive compounds in the extract make the resolving power of HPLC critical for the swift processing of multi-component plant samples on a preparative and analytical scale [37]. Currently, numerous benchtop HPLC instruments possess a modular design and are inclusive of a solvent delivery pump, an auto-sampler or manual injection valve, a guard column, an analytical column, a detector, and a recorder or a printer [37]. HPLC can be employed for chemical separations because the constituents of the extract possess distinct migration rates and certain parameters are established. Ultimately, the mobile phase and stationary phase chosen determines the extent of separation [37]. An isocratic system (makes use of a single mobile phase system) is the general method utilized for the separation and identification of phytochemicals. However, if multiple sample components are of interest to the researcher, it would be ideal to employ gradient elution that involves the modification of the organic and aqueous proportions over a specified amount of time [37]. Gradient elution may prove challenging if the analytes possess analogous properties and similar retention times.

In HPLC, purification can be achieved by separating the compound of interest from other compounds or interferents. Based on the chromatographic conditions selected, each compound will possess a characteristic peak. To separate a variety of compounds, the chromatographer has the unique ability to tamper with parameters such as the mobile phase, column type, flow rate, and detectors to ascertain optimal peak resolution and separation [37]. For the identification of compounds, a suitable detector for HPLC must be chosen [37]. The chosen detector should be set to appropriate detection settings and a method is to be developed to yield a clean peak on the chromatogram for the specific analyte being analyzed [37]. UV detectors are quite commonplace among researchers because they afford high sensitivity [38]. Furthermore, phytochemicals of research interest commonly have a UV absorbance at low wavelengths that ranges from 190-210 $\mathrm{nm}$ [37]. Apart from UV detectors, other detectors such as the diode array detector (DAD) coupled with a mass spectrometer are employed to assess phytochemicals.

There have been several studies that have been successful in quantifying bioactive compounds present in plant material. The paramount purpose of the research performed by Sakipova et al. (2017) was to establish an efficient and distinct method for santonin identification and quantification with the use of HPLC [39]. The researchers more specifically desired to diminish unwarranted intoxication of santonin present in Artemisia cina so that its anthelmintic properties can be used in veterinary medicine [39]. The method developed from this research was utilized to characterize and quantify santonin levels in the leaves of eight distinct Artemisia species: A. cina, A. scoparia, A. absinthium, A. terra-albae, A. gmelinni, A. sublesingiana, A. schrenkiana, and A. frigida [39]. The primary result of this investigation 
demonstrated that santonin in Artemisia cina possessed a retention time was approximately 5.7 min, a time congruent with the Santonin standard tested [39].

The HPLC system (Waters) was employed for the quantitative analysis of santonin equipped with the breeze software program, Waters 717 plus autosampler, Waters 1525 binary HPLC pump, and Waters 2487 dual wavelength absorbance detector [39]. The solvent system applied was water (solvent $\mathrm{A}$ ) and acetonitrile (solvent $\mathrm{B}$ ). The gradient elution program utilized was: $35 \% \mathrm{~A}-65 \%$ B at $0 \mathrm{~min}, 35 \% \mathrm{~A}-65 \% \mathrm{~B}$ for $5 \mathrm{~min}, 45 \%$ A-55\% B for $10 \mathrm{~min}, 55 \% \mathrm{~A}-45 \% \mathrm{~B}$ for $15 \mathrm{~min}$, and $65 \% \mathrm{~A}-45 \%$ B for $20 \mathrm{~min}$ [39]. The chosen HPLC system parameters for the wavelength and pressure were $236 \mathrm{~nm}$ and $5000 \mathrm{~atm}$, respectively [39]. HPLC chromatogram for chloroform extract from Artemisia cina is shown in Figure 3.

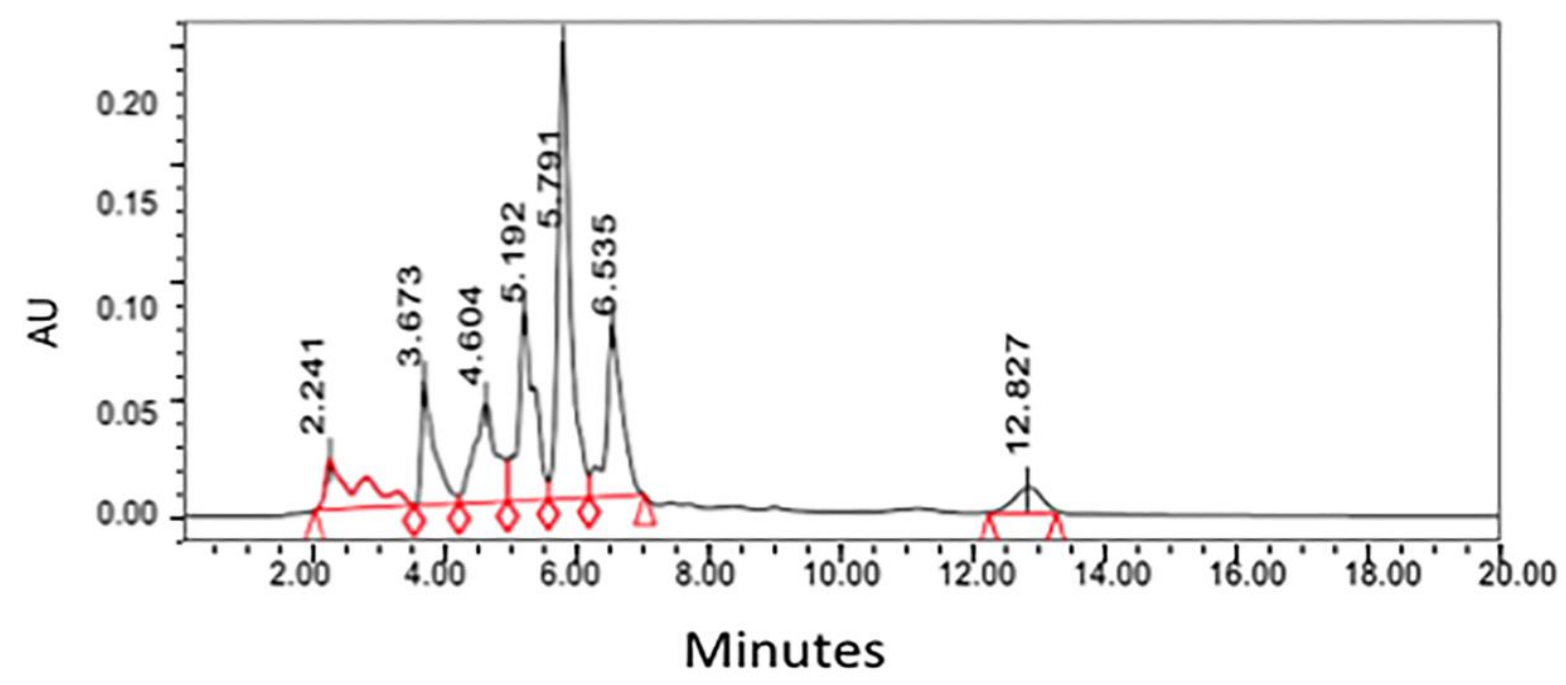

Figure 3. HPLC chromatogram for chloroform extract from Artemisia cina [39]. Peak at 5.7 represents santonin and quantified by the standard of santonin run with same HPLC condition.

In another investigation led by Tian et al. (2020), six phenolic acids derived from Artemisia capillaris (Yinchen) were analyzed using HPLC and their transformation pathways assessed during the decoction process [40]. The intent of this research was to establish and corroborate a novel analytical protocol for the analysis of phenolic acids such as 4,5dicaffeoylquinic acid, 3,4-dicaffeoylquinic acid, 1,3-dicaffeoylquinic acid, 4-caffeoylquinic acid, and 3-caffeoylquinic acid to achieve "quality control" of A. capillaris decoction [40]. To accomplish this purpose, HPLC coupled with diode array detection (HPLC-DAD) was employed [40].

The HPLC system utilized for the quantitative investigation of the six phenolic acids was a Thermo UltiMate 3000 (USA) containing an autosampler, a column temperature controller, and a DAD (190-300 nm) [40] is shown in Figure 4. To maintain the column temperature at $30{ }^{\circ} \mathrm{C}$, an Agilent Eclipse $\mathrm{XDB}-\mathrm{C}_{18}$ column $(250 \mathrm{~mm} \times 4.6 \mathrm{~mm})$ with a particle size of $5 \mu \mathrm{m}$ was used [40]. The applied solvent system was a $0.1 \%$ formic acid in water (solvent A) and acetonitrile (solvent B) [40]. The gradient elution program employed was: $7-15 \%$ B for $0-20$ min (linear gradient), $15-20 \%$ B for $20-30$ min (linear gradient), $20 \%$ B for $30-35 \mathrm{~min}$ (isocratic gradient), and $20-25 \%$ for $35-45 \mathrm{~min}$ (linear gradient) [40]. With an injection volume of $5 \mu \mathrm{L}$ and a $5 \mathrm{~min}$ post-run at a flow rate of $1.0 \mathrm{~mL} / \mathrm{min}$, a high resolution of the desired compound peaks was achieved [40]. 


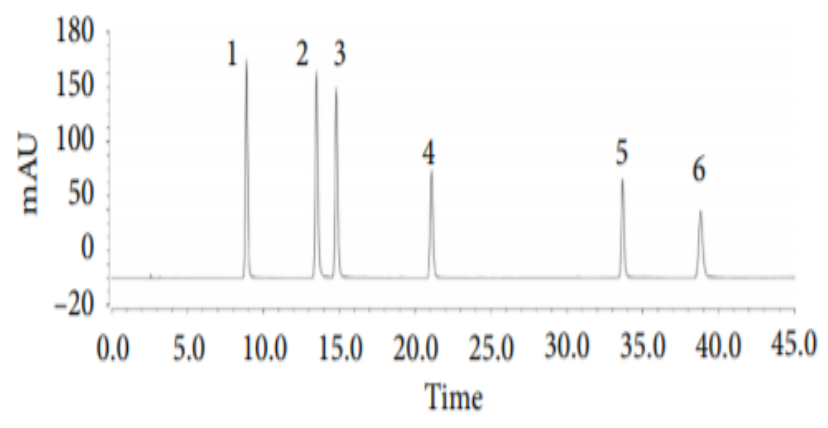

(a)

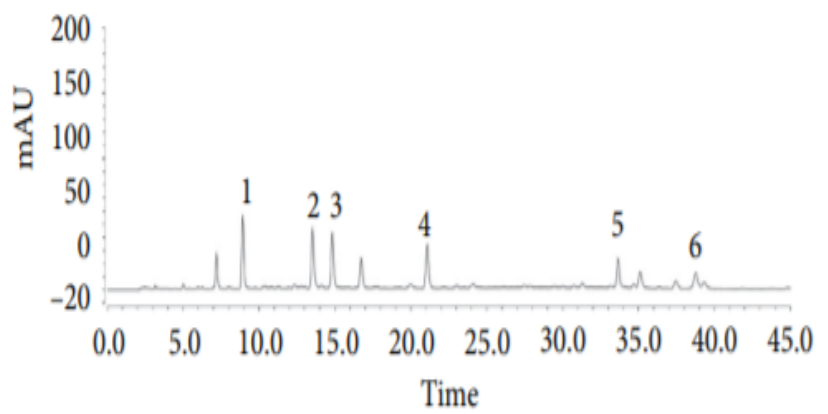

(b)

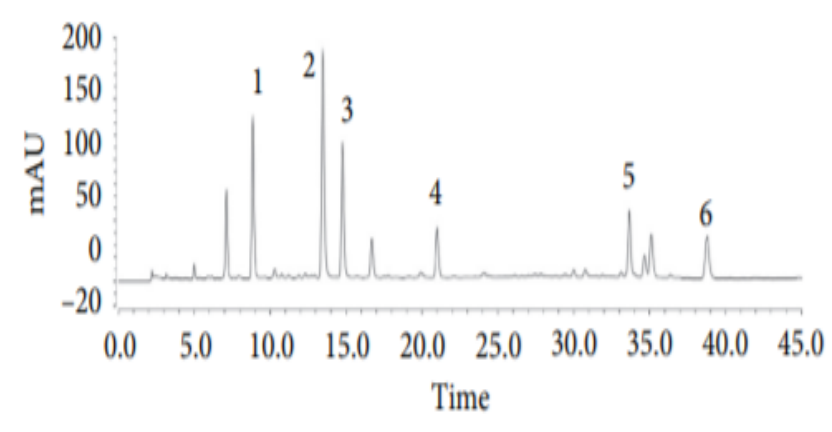

(c)

Figure 4. Representative HPLC chromatograms of (a) mixed standards; (b) A. capillaris herb; (c) A. capillaris decoction. Each numerical number signifies respective compounds: (1) 5-Caffeoylquinic acid; (2) 3-caffeoylquinic acid; (3) 4-caffeoylquinic acid; (4) 1,3-dicaffeoylquinic acid; (5) 3,4-dicaffeoylquinic acid; (6) 4,5-dicaffeoylquinic acid [40].

\subsection{Characterization: LCMS \& NMR}

Liquid chromatography coupled with a mass spectrometer (LC-MS) is a salient and efficacious technique utilized for the analysis of intricate botanical extracts [37]. With the simultaneous application of tandem mass spectrometry, LC-MS can provide ample data for the structural determination of bioactive compounds [37]. The research carried out by Wang et al. aimed to develop an LC-MS method accompanied by selected ion monitoring (SIM) for the quantification of artemisinin from various locations [41]. To track "the abundance of the $[\mathrm{M}-18+\mathrm{H}]^{+}$ion peak at $m / z 265.5^{\prime}$, SMI was employed, and a scan range from $m / z 250$ to 270 was used [41]. As a result of monitoring the [M-18+H] ${ }^{+}$ion peak, LC-MS sensitivity was propitiously enhanced [41] as shown in Figure 5. The method developed from this research offers a straightforward and accurate manner to detect and quantify artemisinin with a total run time of $11 \mathrm{~min}$ per sample [41]. 


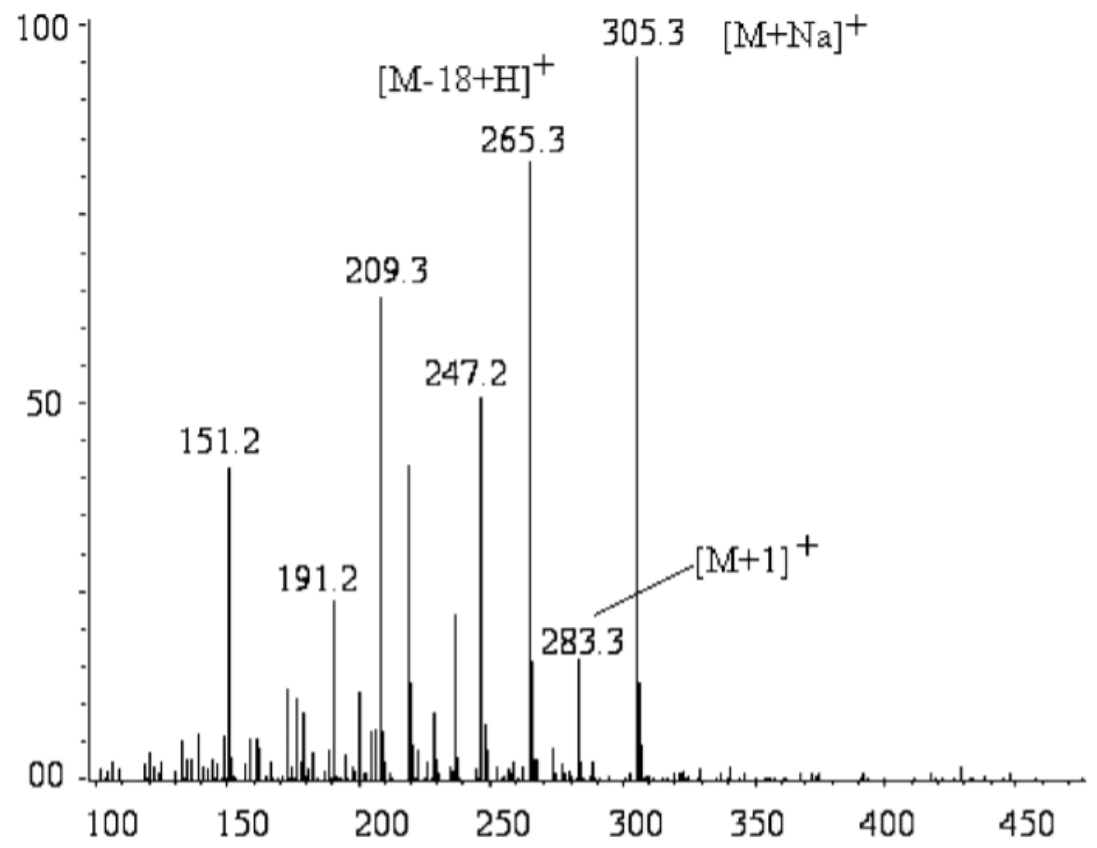

Figure 5. Mass spectrum of artemisinin under positive ion mode [41], where $283.3[\mathrm{M}+1]^{+}$represents artemisinin; $305.3[\mathrm{M}+\mathrm{Na}]^{+}$represents sodium adduct of artemisinin.

The motive behind the research conducted by Pratibha Singh et al. in 2020 was to identify and determine bioactive compounds in the ethanolic extracts of various Artemisia species for anti-malarial and anti-diabetic purposes shown in Figure 6 [42]. To achieve this end, the researchers established the "Ultra Performance Liquid Chromatography coupled with hybrid triple quadrupole linear ion trap tandem mass spectrometry (UPLC-ESIQqQLIT-MS/MS) method in multiple reaction monitoring (MRM) acquisition mode" [43]. The method developed was then substantiated using recovery, linearity, stability, precision, limit of detection (LOD), and limit of quantitation (LOQ) [42]. There are several analytical techniques in existence that have been applied to probe the nature of a variety of bioactive constituents innate in Artemisia species such as gas chromatography-mass spectrometry (GC-MS), high-performance liquid chromatography (HPLC), and high-performance thinlayer chromatography (HPTLC) [42]. However, the previously mentioned techniques are considered to be lacking due to a variety of limitations, some of which may be attributed to their lower selectivity and sensitivity [43]. With a more advanced technique such as the UPLC-ESI-QqQLIT-MS/MS), which is an accurate and largely accepted technique, copious metabolites in complex plant extracts can be identified and quantified by applying multiple reactions monitoring (MRM) mode [42]. In this study, the developed method was used to investigate the bioactive components in different Artemisia species such as $A$. vulgaris, A. absinthium, A. dracunculus, A. annua, A. maritima, A. vestita, and A. verlotiorum [42]. 


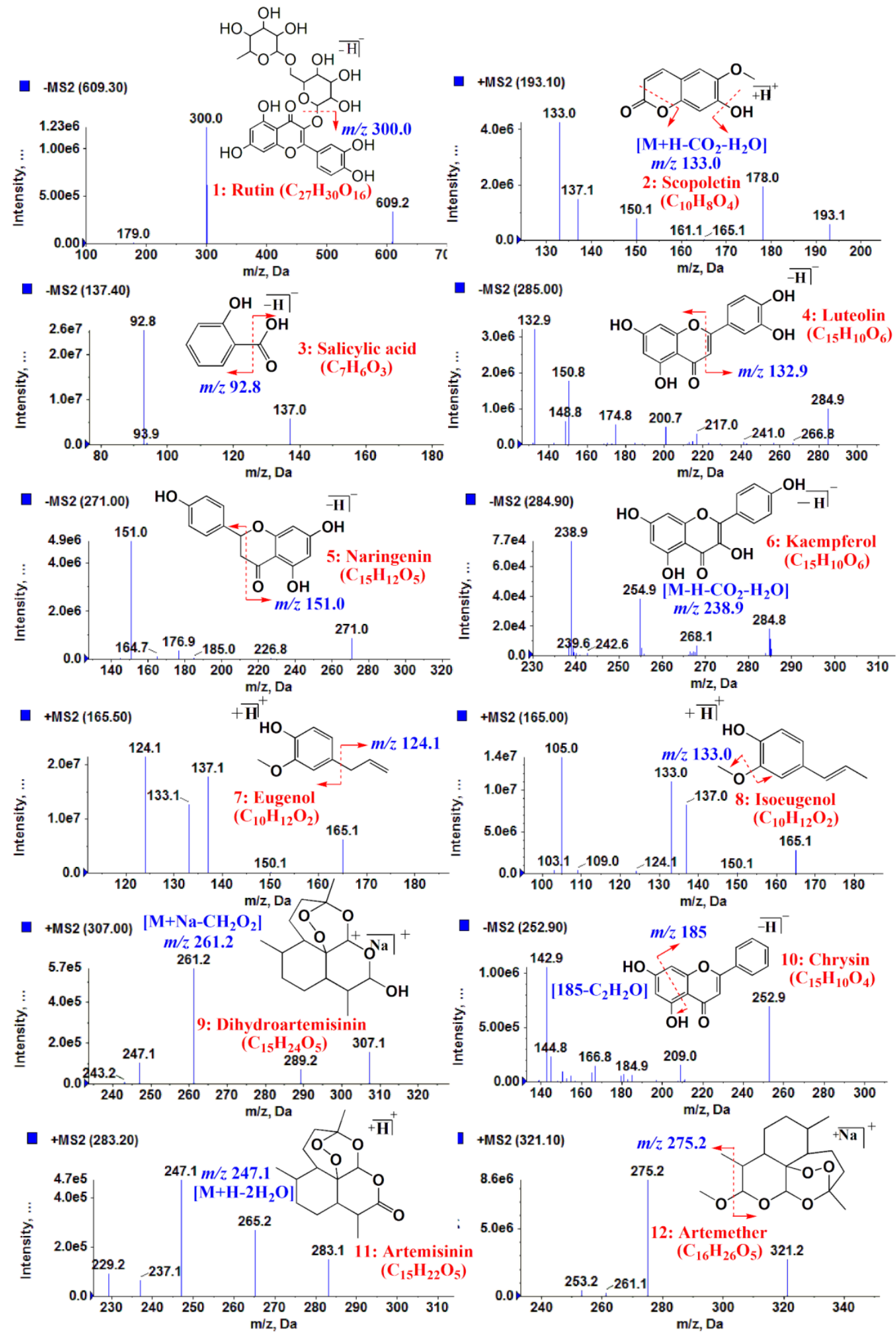

Figure 6. ESI-MS/MS spectra in positive and negative mode in addition to MRM transitions of various Artemisia species [42]. As per the report, peaks 1, 4, 5, 6 and 10, were identified as rutin, luteolin, naringenin, kaempferol and chrysin respectively. Peaks 7 and 8 were detected as eugenol and isoeugenol and peaks 9, 11 and 12 were detected as dihydroartemisinin, artemisinin and artemether, respectively. 
Nuclear magnetic resonance (NMR) spectroscopy is a remarkably useful instrument for the investigation of the chemical constituents in extracts of a specific sample. Researchers have utilized NMR extensively in search of drug candidates derived from natural products, structure-based drug design, and drug discovery [43]. In a study performed by Nageeb et al. (2013), ${ }^{1} \mathrm{H}$ NMR was employed to juxtapose the diverse metabolites contained in Artemisia annua garnered from Egypt and Jericho presented in Figure 7 [43]. Various organic extracts and aqueous extracts used in traditional medicine were utilized to compare the biological activities of Artemisia annua from Egypt (EA) and Artemisia annua from Jericho (JA) [43]. NRM analysis served to corroborate the differences in the bioactivity of EA and JA. The higher temperatures and arid weather conditions in Jericho afforded the JA extracts (water and methanol) greater antibacterial and antioxidant activities than the extracts from Egypt [43]. Conversely, the methanol extract of $A$. annua from Egypt demonstrated high anticancer activity while the EA water extract and both JA extracts displayed meager anticancer activity [43]. Overall, the results of this study conclude that environmental influences play an appreciable role in the various bioactive compounds present in A. annua species from Egypt and Jericho [43].
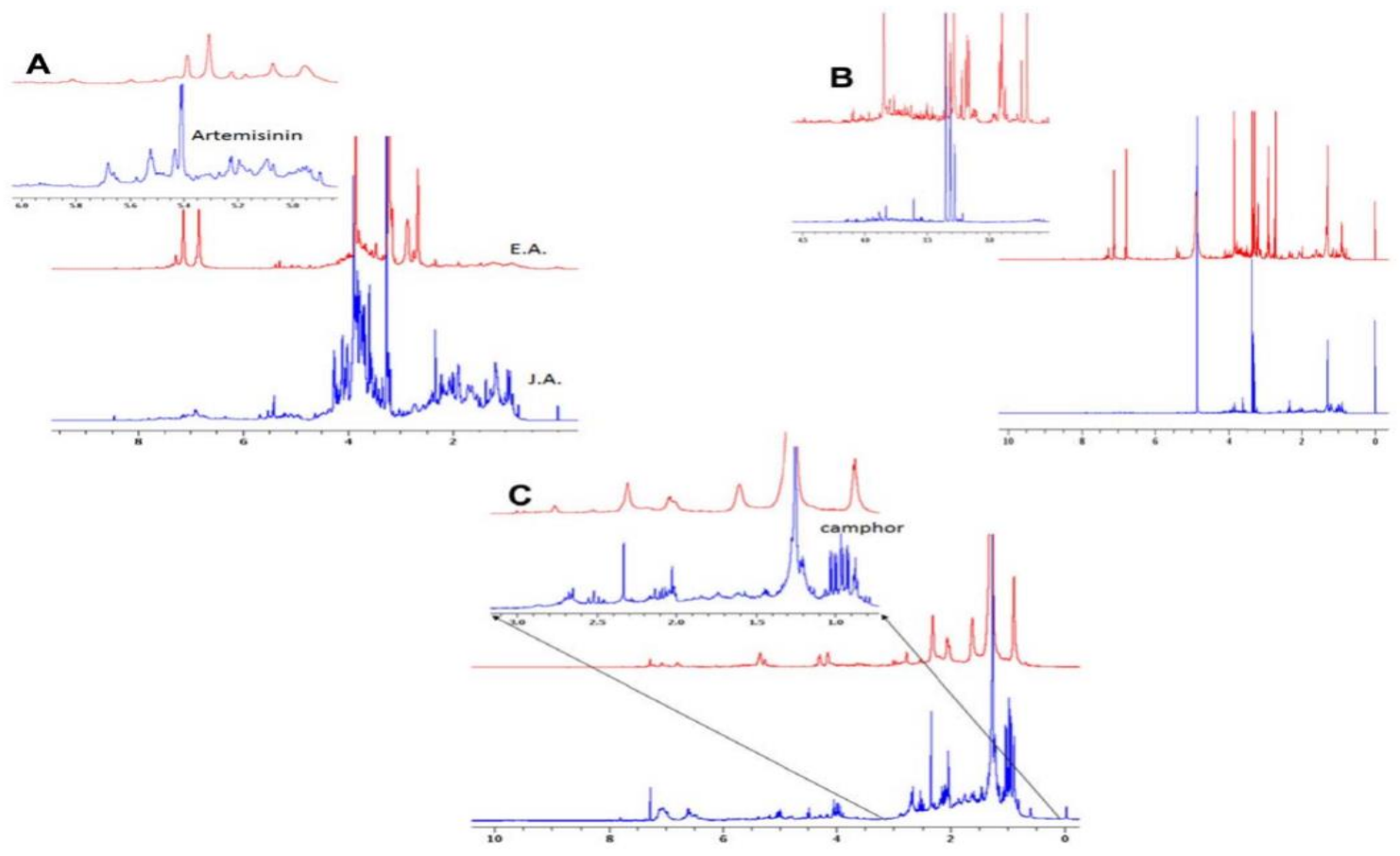

Figure 7. NMR analyses of the chemical compositions of the hexane-chloroform, methanol and water extracts of both EA and JA. The NMR spectrum of EA and JA water extracts (a). The NMR spectrum of EA and JA hexane-chloroform extracts (b). The NMR spectrum of the JA and EA methanol extracts (c). [43].

\section{Bioactive Compounds from Artemisia}

\subsection{Phenolics \& Flavonoids}

As mentioned previously, a vast assortment of secondary metabolites dwells in plants. Phenolics are compounds synthesized by flora as a part of their natural development process and during stressful conditions such as UV radiation exposure, injury, and predation [44]. As a class, phenolics are structurally distinguished by their aromaticity and having a minimum of one hydroxyl group directly connected to a benzene ring [44]. Plants are a significant source of the structurally diverse class of phenolics, with over 8000 phenolics extracted from plants [44]. The structural diversity of phenolics is complemented with their protective role against eclectic ailments such as stroke, coronary heart disease, and specific types of cancer [44]. 
The three fundamental classes of phenolics are polyphenols (flavonoids and tannins), simple phenols (phenolic acids), terpene and a miscellaneous class [44], and they are represented in Figure 8. Polyphenols are bioactive compounds that are copious and well distributed in a great variety of plants in disparate locations [45]. Polyphenols possess antioxidant properties that serve to mollify the insidious impacts of free radicals. Polyphenols also impart color to vegetables, fruits, and flowers [45]. Typically, polyphenols are further organized into two rudimentary classes: flavonoids and tannins [44,45]. Tannins are considered to be acerbic "plant polyphenols that bind or precipitate proteins" [44]. These acerbic compounds are further organized into two primary subclasses, condensed and hydrolysable. Flavonoids are a highly diverse class of phenolic compounds. These compounds are commonly found in flowers, vegetables, stems, roots, barks, grains, fruits, tea, and wine [46]. Flavonoids are considered to be the most substantial class of phytonutrients [46]. The colors of vegetables, fruits, and other vibrantly colored parts of plants can be ascribed to the presence of flavonoids [46]. This wide-ranging class of compounds satisfy an assortment of physiological functions in flora. In the flavonoid class, there exist subclasses which are inclusive of isoflavones, flavones, flavanols, flavonols, flavanones, dihydroflavonols, bioflavonoids, chalcones, and aurones [44,45]. Various polyphenols compounds found in A. herba alba [17] and A. vulgaris [5] is shown in Figures 8 and 9.
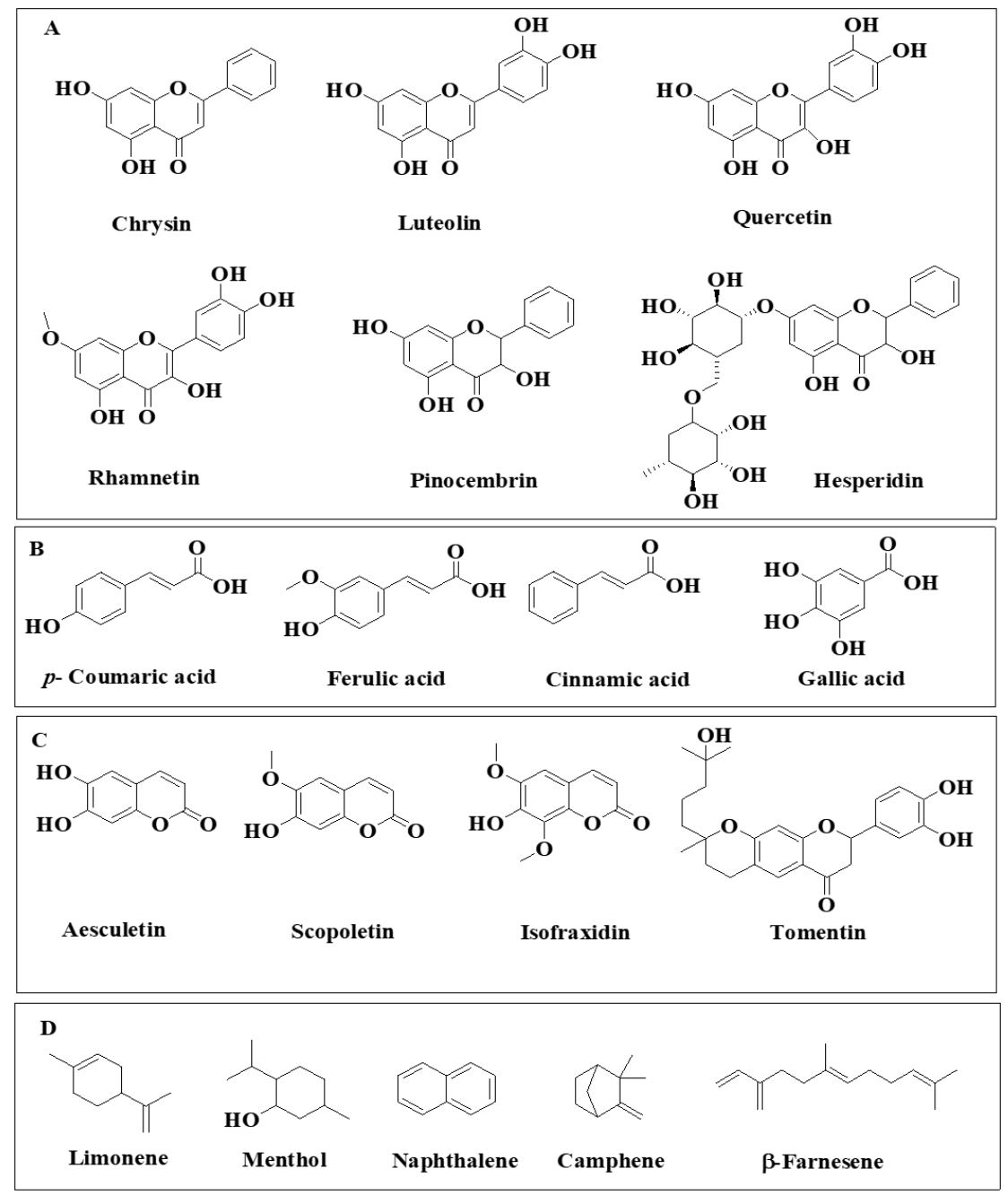

Figure 8. The fundamental classes of bioactive compounds present in Artemisia: (A) flavonoids; (B) phenolic acids; (C) coumarin; (D) terpene. 

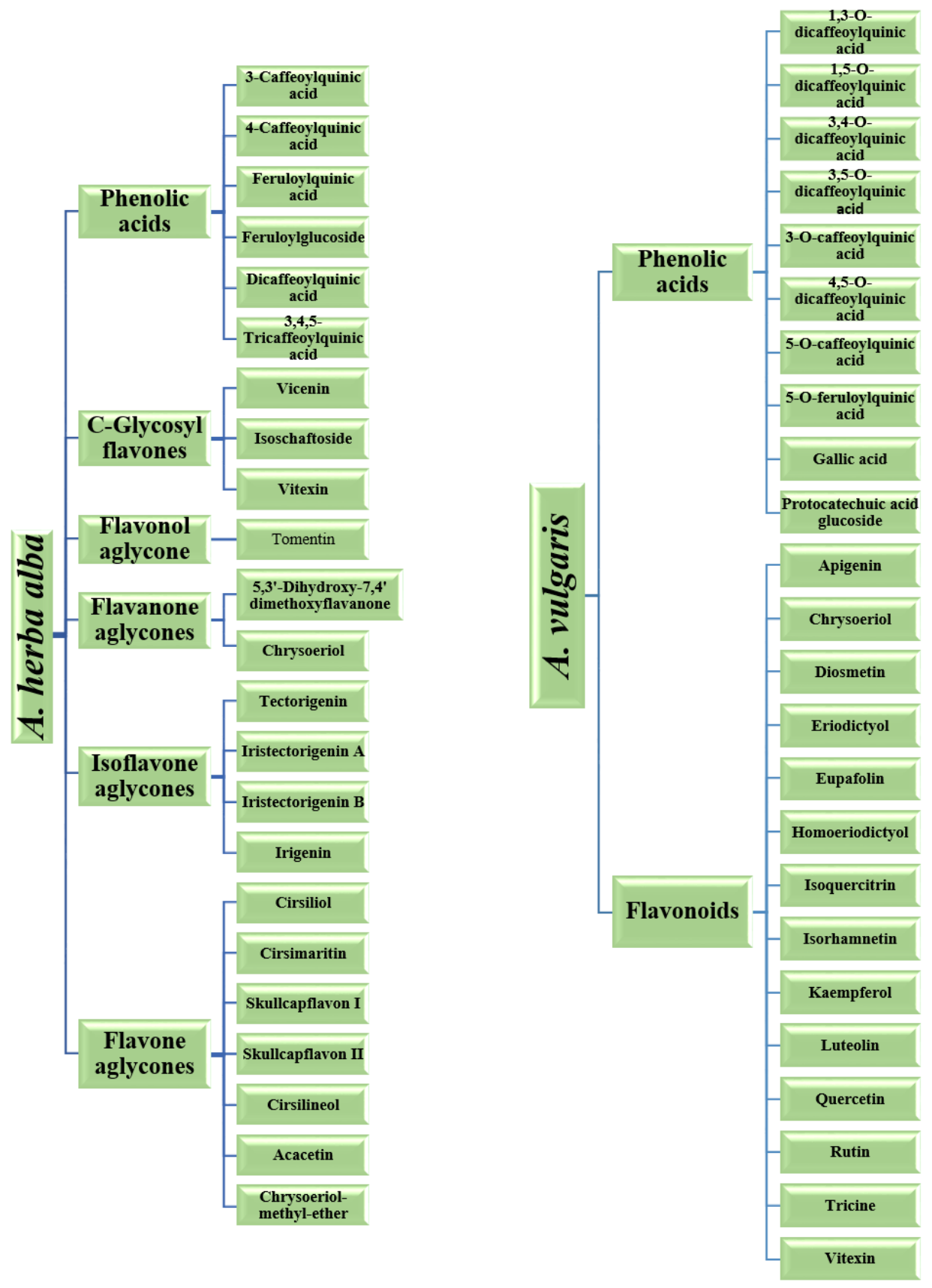

Figure 9. Various bioactive compounds found in A. herba alba [17] and A. vulgaris [5].

\subsection{Terpenoids}

Terpenoids are yet another consequential class of bioactive compounds present in Artemisia species. Terpenoids are the most abundant class of natural products in plants with over 40,000 unique structures [47]. Five-carbon isoprene units serve as the fundamental building blocks of this class. The amount of isoprene units incorporated into the structure determines the various classifications: hemiterpenes $\left(C_{5}\right)$, monoterpenes $\left(C_{10}\right)$, sesquiterpenes $\left(C_{15}\right)$, diterpenes $\left(C_{20}\right)$, triterpenes $\left(C_{30}\right)$, tetraterpenes $\left(C_{40}\right)$, and polyterpenes [47].

\subsection{Coumarins}

Naturally occurring coumarins can exist as aglycones or as glycosides and are widely distributed in more than 30 families, including about 150 species of plants. Coumarins are a class of compounds with a characteristic fragrant odor. Coumarin is the lactone derived 
from cis-ortho-hydroxycinnamic acid, known as benzo- $\alpha$-pyrone or benzo-1,2-pyrone. They are formed in the leaves and accumulate especially in the roots and bark, as well as in old or damaged tissues. Coumarins protect plants from herbivores and pathogenic microorganisms. The main coumarins found in Artemisia are shown in Figure 10.

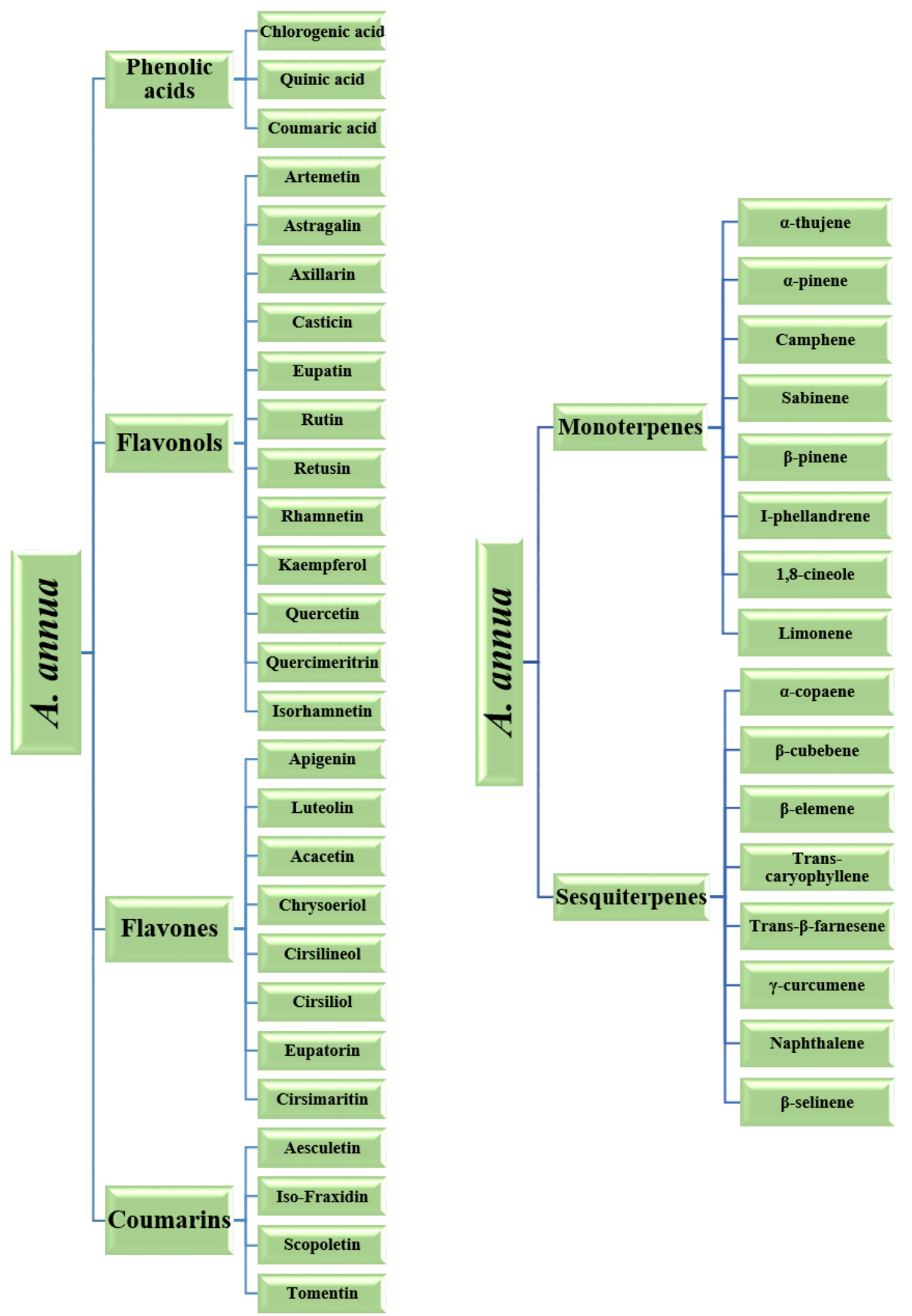

Figure 10. Illustration of the various bioactive compounds found in A. annua [17].

\section{Biological Properties \& Significance}

The richness in the biological properties of Artemisia species can be imputed to the diversity of the secondary metabolites present in sagebrush [1]. Some of the most notable biological activities of Artemisia species are antitumor, anti-inflammatory, antiulcer, and antimicrobial [1]. Table 2 shows the health bolstering effects of Artemisia extracts. The biological activities of this species have considerably aided in promoting the health of millions globally [1]. 
Table 2. Health bolstering effects of Artemisia extracts.

\begin{tabular}{|c|c|c|c|}
\hline $\begin{array}{l}\text { Artemisia } \\
\text { Species Extract }\end{array}$ & Salient Applications & Animal Model and Cell Lines Used & Reference \\
\hline $\begin{array}{l}\text { Artemisia } \\
\text { absinthium }\end{array}$ & $\begin{array}{l}\text { Demonstrated reduction in the overall } \\
\text { cholesterol level in diabetic rats through } \\
\text { inhibition of enzyme activities involved in } \\
\text { cholesterol biosynthesis }\end{array}$ & Alloxan-induced diabetic rats & {$[17,48]$} \\
\hline Artemisia annua & $\begin{array}{l}\text { Mice fed } A \text {. annua extract diet demonstrated } \\
\text { diminished levels of malondialdehyde, a } \\
\text { biomarker of lipid peroxidation. } \\
\text { Studies demonstrated the use of } A \text {. annua extract } \\
\text { has high anticancer effects }\end{array}$ & $\begin{array}{l}\text { C57BL/6J mice Human Breast } \\
\text { Adenocarcinoma MCF7 (BA), Human Lung } \\
\text { Carcinoma (LC) and Chinese Hamster Ovary } \\
\text { (CHO) cell lines and Primary Human Dermal } \\
\text { Fibroblasts isolated from adult skin (HDFa) } \\
\text { cells were used }\end{array}$ & {$[43,49]$} \\
\hline Artemisia biennis & $\begin{array}{l}\text { Fractions of } A \text {. biennis have been shown to stifle } \\
\text { generation of reactive oxygen species (ROS) } \\
\text { while improving the activity of superoxide } \\
\text { dismutase (SOD). }\end{array}$ & PC12 Cells & {$[8]$} \\
\hline $\begin{array}{l}\text { Artemisia } \\
\text { campestris }\end{array}$ & $\begin{array}{l}\text { Antioxidant activity of } A \text {. campestris was } \\
\text { revealed in a study that exposed rats to induced } \\
\text { oxidative stress from a puffer fish. The rats were } \\
\text { then fed aqueous extracts of } A \text {. campestris, } \\
\text { resulting in the inhibition of thiobarbituric acid } \\
\text { reactive substance (TBARS) and the } \\
\text { amplification of antioxidant enzyme activities } \\
\text { such as glutathione peroxidase (GSH-Px) and } \\
\text { superoxide dismutase (SOD) in the brain, liver, } \\
\text { and kidney. }\end{array}$ & Rats & {$[11]$} \\
\hline $\begin{array}{l}\text { Artemisia } \\
\text { douglasiana }\end{array}$ & $\begin{array}{l}\text { A. douglasiana leaf essential oil has been shown } \\
\text { to be an efficacious complementary treatment for } \\
\text { recurring urinary tract infection. }\end{array}$ & Studied in rodents & {$[14]$} \\
\hline $\begin{array}{l}\text { Artemisia } \\
\text { dracunculus }\end{array}$ & $\begin{array}{l}\text { A. dracunculus is typically used to enhance a } \\
\text { poorly functioning digestive system by } \\
\text { improving appetite to remove toxins from the } \\
\text { body. In cultures with a particularly high intake } \\
\text { of red meat, } A \text {. dracunculus is employed as a } \\
\text { digestive stimulant. }\end{array}$ & Phenylbutazone-induced ulcer in rats & {$[14]$} \\
\hline $\begin{array}{l}\text { Artemisia } \\
\text { tridentata }\end{array}$ & $\begin{array}{l}\text { A. tridentata possesses anthelmintic activity } \\
\text { which is useful in the treatment of oxyuriasis } \\
\text { and ascariasis by inducing paralysis on the } \\
\text { worm to flush out the parasite from the bowls. }\end{array}$ & - & {$[17]$} \\
\hline $\begin{array}{l}\text { Artemisia } \\
\text { vulgaris }\end{array}$ & $\begin{array}{l}\text { The antihypertensive activity of } A \text {. vulgaris has } \\
\text { been demonstrated to limit the hypertensive } \\
\text { effects of noradrenaline } \\
\text { Cytotoxic activity inhibits growth of tumor cells } \\
\text { in cancer cell lines }\end{array}$ & $\begin{array}{l}\text { Isolated perfused rat mesentery } \\
\text { SW-480, MCF7, HL-60, HeLa, 293T, and } \\
\text { A7R5. }\end{array}$ & [32] \\
\hline
\end{tabular}

\subsection{Antitumor Activity}

Artemisinin and its derivatives from A. аnпиа (artemisone, artesunate, dihydroartemisinin, and artemether) are highly potent antimalarial drugs [36]. They are efficacious anticancer compounds because they are exceptionally selective to cancer cells while producing nearly minimal adverse effects on healthy cells [36]. The application of these bioactives is far-reaching and encompasses a broad spectrum of utility in leukemia, breast, melanoma, prostate, and lung cancer cells [36]. The basis of artemisinin's antitumor mechanism is the cleavage of its endoperoxide bridge by the iron in cancerous cells along with the formation of free radicals [36]. Other bioactive compounds such as flavonoids also play a part in the holistic activity of A. annua extracts [45]. Specifically, the flavonoids in A. annua perform "synergically" with artemisinin to diminish cancer and malaria by altering the metabolism and absorption of artemisinin in the body [45]. 


\subsection{Anti-Inflammatory \& Immunomodulatory Activity}

The sesquiterpene lactones from the Artemisia genus also demonstrate anti-inflammatory and immunomodulatory influence that could refine the treatment of chronic diseases and thereby, the success of therapy. The rudimentary mechanism of action for anti-inflammatory activity is the inhibition of nuclear factor $\mathrm{\kappa B}$ (NF- $\mathrm{KB}$ ). NF- $\mathrm{KB}$ is family of inducible transcription factors and a well know complex protein that functions to modulate $150+$ inflammatory genes, DNA transcription and mediates the immune response in humans [36]. Thus, the inhibition of NF- $\mathrm{KB}$ minimizes inflammatory response and derails cancer proliferation. NF- $\mathrm{kB}$ involved in cellular responses to stimuli and has been linked to cancer, inflammatory and autoimmune diseases, septic shock, viral infection, and improper immune development [50]. In a dose-dependent fashion, artemisinin precludes the "secretion of tumor necrosis factor (TNF)- $\alpha$, interleukin-(IL-) $1 \beta$, and IL-6", which imparts an "antiinflammatory effect on phorbol myristate acetate-(PMA-) induced THP-1 human monocytes" [36]. Furthermore, sesquiterpene lactones such as arteannuin B, dihydroartemisinin, artemisinic acid, and artemisinin considerably diminish "LPS-activated production of prostaglandin E2 (PGE2)" which is an inflammatory mediator bolsters tumor growth [36].

\subsection{Antiulcer Activity}

The alpha-methylene-gamma-lactone moiety of sesquiterpene lactones from Artemisia are responsible for the antiulcerogenic activity these compounds exhibit [51]. A. annua's crude extract and the sesquiterpene lactone enriched fraction from the aerial parts displayed "antiulcerogenic activity on the indomethacin induced ulcer in rats" [36]. Three divergent polarity fractions were gleaned from the sesquiterpene lactone fraction utilized to perform column chromatography. The medium polarity fraction revealed that the active compounds of $A$. аnnua perform their function by elevating the "prostaglandin levels in the gastric mucosa" [36].

\subsection{Antimicrobial Activity}

The antiparasitic activity of artemisinin and its analogs displayed its effects against Plasmodium species both in vitro and in vivo. These compounds have proven effective against "multidrug resistant strains of the malaria parasite" and in cerebral malaria cases [36]. The antimalarial properties of artemisinin can be attributed to the endoperoxide bridge in its structure [36]. The action mechanism involves the interaction of the endoperoxide group with the endoparasitic iron which results in the establishment of free radicals [36]. The free radicals derived from artemisinin alkylate are the "malarial-specific proteins" that compromise the membranes and micro-organelles of the parasite [36]. Lastly, the radicals degrade the infected blood cells, which prompts the removal of the cell by the immune system of the host [36]. Moreover, artemisinin also targets the mitochondria of the parasite which is critical to the proper functioning of the parasite [36]. The key functional part of artemisinins and their analogues is the endoperoxidic bridge to which its antimalarial properties are attributed. The direct interaction of the endoperoxidic group of artemisinins with the intraparasitic iron results in the production of free radicals, which later damage the micro-organelles and membranes of the parasite [36]. The lifesaving drug "Artemisinin" is a secondary metabolite from Artemisia annua. This bioactive compound garnered clinical significance as a first in-class antimalarial drug with a clinical trial from the leaf extract of $A$. annua directed by Prof. Youyou Tu. This study was performed in August 1972 at Hainan Island on 21 patients, achieving $95-100 \%$ efficacy. It is ironic that she took the medicine herself to evaluate the safety of the extract. This ground-breaking clinical achievement led Prof. Youyou Tu to achieve a Nobel Prize in Physiology or Medicine in 2015 [52]. Recently, more attention has been paid to artemisinin's application for treating various diseases such as antiproliferation [53], antifibrosis [54], antiviral [55], and renal protective [56]. Artemisinins have excellent anti-inflammatory and immunoregulatory functions due to its property of keeping good balance between oxidation and oxidation resistance, which is the cause of various diseases. Still, the mode of action of artemisinin 
is debatable among the scientific community because the detailed mechanism of action is still highly controversial [57]. The endoperoxide pharmacophore alone has stimulated the development of several different classes of endoperoxides and has been included in Figure 11.

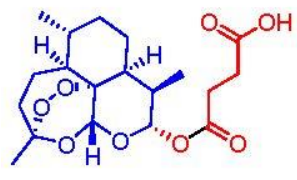

Artesunate

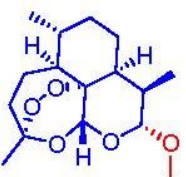

Artemether

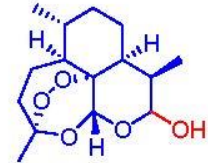

Dihydroartemisinin

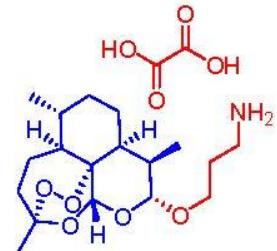

SM934 (B-Aminoarteether

Figure 11. Artemisinin's derivatives.

The key extraction process involved using a cold temperature from the plant. Prof. Tu utilized ether replacing ethanol and chose leaves to obtain a concentrated artemisinin biomedicinal agent without heating. Ether with low boiling point is used in extraction processes with functional groups which are unstable by heating. The structure of artemisinin has a unique 1,2,4-trioxane peroxide pharmacophore supports this observation. Peroxides are unstable under heating conditions, but this pharmacophore was used toward development of analogs containing trioxolane functionality [58].

\section{Conclusions}

Artemisia species are the hardy herbaceous vegetation that are mainly grown in dry or semi-arid habitats. These plant species consist of terpenoids, phenolic compounds and flavonoids as the chief bioactive compounds, which are generally responsible for giving the plant species the characteristic bitter tastes and strong aromas. In addition, these secondary metabolites are also in charge of providing the antitumor, anti-inflammatory, anti-ulcer and anti-microbial activities that assist in promoting the health of the global population. For this particular reason, extraction, isolation and characterization of the bioactive compounds of Artemisia species is highly imperative.

Funding: This study was carried out with support from the Office for Research and Department of Chemistry at Idaho State University, and the Center for Advanced Energy Studies (CAES). This research was also partially supported by funding from the Ronald E. McNair Post Baccalaureate Achievement Program at Idaho State University, which is sponsored by the Department of Education (P217A170169).

Institutional Review Board Statement: Not applicable.

Informed Consent Statement: Not applicable.

Data Availability Statement: Not available.

Conflicts of Interest: The authors declare no conflict of interest.

\section{References}

1. Brusotti, G.; Cesari, I.; Dentamaro, A.; Caccialanza, G.; Massolini, G. Isolation and Characterization of Bioactive Compounds from Plant Resources: The Role of Analysis in the Ethnopharmacological Approach. J. Pharm. Biomed. Anal. 2014, 87, $218-228$. [CrossRef] [PubMed]

2. Bora, K.S.; Sharma, A. The Genus Artemisia: A Comprehensive Review. Pharm. Biol. 2011, 49, 101-109. [CrossRef]

3. Abad, M.J.; Bedoya, L.M.; Apaza, L.; Bermejo, P. The Artemisia L. Genus: A Review of Bioactive Essential Oils. Molecules 2012, 17, 2542-2566. [CrossRef] [PubMed]

4. Weston, L.; Barney, J.; DiTommaso, A. A Review of the Biology and Ecology of Three Invasive Perennials in New York State: Japanese Knotweed (Polygonum cuspidatum), Mugwort (Artemisia vulgaris) and Pale Swallowwort (Vincetoxicum rossicum). Plant Soil 2005, 277, 53-69. [CrossRef] 
5. Abiri, R.; Silva, A.L.M.; de Mesquita, L.S.S.; de Mesquita, J.W.C.; Atabaki, N.; de Almeida, E.B.; Shaharuddin, N.A.; Malik, S. Towards a Better Understanding of Artemisia Vulgaris: Botany, Phytochemistry, Pharmacological and Biotechnological Potential. Food Res. Int. 2018, 109, 403-415. [CrossRef]

6. Available online: https:// plants.sc.egov.usda.gov/home (accessed on 11 November 2020).

7. Datasheet Report for Artemisia biennis (Biennial Wormwood). Available online: https://www.cabi.org/isc/datasheetreport/1124 41 (accessed on 19 June 2020).

8. Mojarrab, M.; Mehrabi, M.; Ahmadi, F.; Hosseinzadeh, L. Protective Effects of Fractions from Artemisia Biennis Hydro- Ethanolic Extract against Doxorubicin-Induced Oxidative Stress and Apoptosis in PC12 Cells. Iran. J. Basic Med. Sci. 2016, 19, 8.

9. Biennial Wormwood (Artemisia biennis) I Idaho Fish and Game. Available online: https://idfg.idaho.gov/species/taxa/45280 (accessed on 22 December 2020).

10. Ivanescu, B.; Lungu, C.; Vlase, L.; Gheldiu, A.M.; Grigorescu, C.; Corciova, A. Bioactive Compounds from Artemisia campestris L. Subsp. Campestris. Rev. Chim. 2018, 69, 3076-3081. [CrossRef]

11. Dib, I.; El Alaoui-Faris, F.E. Artemisia Campestris L.: Review on Taxonomical Aspects, Cytogeography, Biological Activities and Bioactive Compounds. Biomed. Pharmacother. 2019, 109, 1884-1906. [CrossRef]

12. Setzer, W.N.; Vogler, B.; Schmidt, J.M.; Leahy, J.G.; Rives, R. Antimicrobial Activity of Artemisia Douglasiana Leaf Essential Oil. Fitoterapia 2004, 75, 192-200. [CrossRef]

13. Watson, L. CalPhotos: Artemisia douglasiana California Mugwort. Available online: https://calphotos.berkeley.edu/cgi/img_ query? (accessed on 23 December 2020).

14. Obolskiy, D.; Pischel, I.; Feistel, B.; Glotov, N.; Heinrich, M. Artemisia dracunculus L. (Tarragon): A Critical Review of Its Traditional Use, Chemical Composition, Pharmacology, and Safety. J. Agric. Food Chem. 2011, 59, 11367-11384. [CrossRef]

15. Aglarova, A.M.; Zilfikarov, I.N.; Severtseva, O.V. Biological Characteristics and Useful Properties of Tarragon (Artemisia dracunculus L.) (Review). Pharm. Chem. J. 2008, 42, 81-86. [CrossRef]

16. Artemisia dracunculus_Plant Finder. Available online: https://www.missouribotanicalgarden.org/PlantFinder/PlantFinderDetails. aspx?taxonid=277563\&isprofile=0\& (accessed on 23 December 2020).

17. Kelley, B.D.; Appelt, J.M.; Appelt, G.D. Artemisia Tridentata (Basin Sagebrush) in the Southwestern United States of America: Medicinal Uses and Pharmacologic Implications. Int. J. Addict. 1992, 27, 347-366. [CrossRef] [PubMed]

18. Monroe, G.A. CalPhotos: Artemisia tridentata ssp. tridentata Basin Big Sagebrush. Available online: https://calphotos.berkeley. edu/cgi/img_query? enlarge=0000+0000+1102+0075 (accessed on 23 December 2020).

19. Anupama. Mugwort (Artemisia vulgaris) Benefits, Uses, Cation and More. Available online: https://www.bimbima.com/health/ artemisia-vulgaris/3726/ (accessed on 23 December 2020).

20. Lee, S.-J.; Chung, H.-Y.; Maier, C.G.-A.; Wood, A.R.; Dixon, R.A.; Mabry, T.J. Estrogenic Flavonoids from Artemisia vulgaris L. J. Agric. Food Chem. 1998, 46, 3325-3329. [CrossRef]

21. Wang, J.; Zhu, F.; Zhou, X.-M.; Nui, C.-Y.; Lei, C.L. Repellent and Fumigant Activity of Essential Oil from Artemisia vulgaris to Tribolium castaneum (Herbst) (Coleoptera: Tenebrionidae). Available online: https://www.researchgate.net/publication/22232540 0_Repellent_and_fumigant_activity_of_essential_oil_from_Artemisia_vulgaris_toTribolium_castaneum_Herbst_Coleoptera_ Tenebrionidae (accessed on 15 June 2020).

22. Lee, J.K. Anti-Inflammatory Effects of Eriodictyol in Lipopolysaccharide stimulated Raw 264.7 Murine Macrophages. Arch. Pharm. Res. 2011, 34, 671-679. [CrossRef] [PubMed]

23. Lopez-Lazaro, M. Distribution and Biological Activities of the Flavonoid Luteolin. Mini-Rev. Med. Chem. 2009, 9, 31-59. [CrossRef] [PubMed]

24. Ekiert, H.; Pajor, J.; Klin, P.; Rzepiela, A.; Ślesak, H.; Szopa, A. Significance of Artemisia vulgaris L.(Common Mugwort) in the history of medicine and its possible contemporary applications substantiated by phytochemical and pharmacological studies. Molecules 2020, 25, 4415. [CrossRef]

25. Govindaraj, S.; Ranjitha Kumari, B.D. Composition and Larvicidal Activity of Artemisia vulgaris L. Stem Essential Oil against Aedes Aegypti. Jordan J. Biol. Sci. 2013, 6, 11-16. [CrossRef]

26. Judzentiene, A.; Garjonyte, R. Compositional Variability and Toxic Activity of Mugwort (Artemisia vulgaris) Essential Oils. Nat. Prod. Commun. 2016, 11. [CrossRef]

27. Chandra, A.; Misra, L.N.; Thakur, R.S. Dihydrofurano-Terpenoids of Davana Oil. Tetrahedron Lett. 1987, 28, 6377-6380. [CrossRef]

28. Haider, F.; Dwivedi, P.D.; Naqvi, A.A.; Bagchi, G.D. Essential Oil Composition of Artemisia Vulgaris Harvested at Different Growth Periods Under Indo-Gangetic Plain Conditions. J. Essent. Oil Res. 2003, 15, 376-378. [CrossRef]

29. Judžentien, A. Chemical Composition of Essential Oils of Artemisia vulgaris L. (Mugwort) from North Lithuania. Chemija 2005, 17, $12-15$.

30. Sharmila, K.; Aadma, P. Effect of Artemisia vulgaris leaf extract on antioxidant status of primary chick embryo fibroblasts. IJPBS 2014, 5, 731-738.

31. Haniya, A.K.; Padma, P. Phytochemical investigation of methanolic extract of Artemisia vulgaris L. leaves. IJPBS 2014, 5, 184-195.

32. Afsar, S.; Kumar, K.R.; Gopal, J.V.; Raveesha, P. Assessment of antiinflammatory activity of Artemisia vulgaris leaves by cotton pellet granuloma method in Wistar albino rats. J. Pharm. Res. 2013, 7, 463-467.

33. Gallego, R.; Montero, L.; Cifuentes, A.; Ibáñez, E.; Herrero, M. Green Extraction of Bioactive Compounds from Microalgae. J. Anal. Test. 2018, 2, 109-123. [CrossRef] 
34. Cao, J.; Yang, M.; Cao, F.; Wang, J.; Su, E. Well-Designed Hydrophobic Deep Eutectic Solvents as Green and Efficient Media for the Extraction of Artemisinin from Artemisia Annua Leaves. ACS Sustain. Chem. Eng. 2017, 5, 3270-3278. [CrossRef]

35. Mannan, A.; Ahmed, I.; Arshad, W.; Asim, M.F.; Qureshi, R.A.; Hussain, I.; Mirza, B. Survey of Artemisinin Production by Diverse Artemisia Species in Northern Pakistan. Malar. J. 2010, 9, 310. [CrossRef]

36. Ivanescu, B.; Miron, A.; Corciova, A. Sesquiterpene Lactones from Artemisia Genus: Biological Activities and Methods of Analysis. J. Anal. Methods Chem. 2015, 2015, 247685. [CrossRef]

37. Sasidharan, S.; Chen, Y.; Saravanan, D.; Sundram, K.; Latha, L. Extraction, Isolation and Characterization Of Bioactive Compounds From Plants' Extracts. Afr. J. Tradit. Complement. Altern. Med. 2010, 8. [CrossRef]

38. Zanousi, M.B.P.; Soleimani, T.; Keyhanfar, M.; Shirali, S.; Raeesi, M. Thin Layer Chromatography (TLC) Technique in the Investigation of Artemisinin Production in Artemisia annua L. Medicinal Plant Hairy Roots. J. Med. Plants Res. 2012, 6, $1842-1845$.

39. Sakipova, Z.; Wong, N.S.H.; Bekezhanova, T.; Sadykova Shukirbekova, A.; Boylan, F. Quantification of Santonin in Eight Species of Artemisia from Kazakhstan by Means of HPLC-UV: Method Development and Validation. PLoS ONE 2017, 12, e0173714.

40. Tian, F.; Ruan, Q.-J.; Zhang, Y.; Cao, H.; Ma, Z.-G.; Zhou, G.-L.; Wu, M.-H. Quantitative Analysis of Six Phenolic Acids in Artemisia capillaris (Yinchen) by HPLC-DAD and Their Transformation Pathways in Decoction Preparation Process. Available online: https: / / www.hindawi.com/journals/jamc/2020/8950324/ (accessed on 13 July 2020).

41. Wang, M.; Park, C.; Wu, Q.; Simon, J.E. Analysis of Artemisinin in Artemisia annua L. by LC-MS with Selected Ion Monitoring. J. Agric. Food Chem. 2005, 53, 7010-7013. [CrossRef] [PubMed]

42. Singh, P.; Bajpai, V.; Khandelwal, N.; Varshney, S.; Gaikwad, A.N.; Srivastava, M.; Singh, B.; Kumar, B. Determination of Bioactive Compounds of Artemisia Spp. Plant Extracts by LC-MS/MS Technique and Their in-Vitro Anti-Adipogenic Activity Screening. J. Pharm. Biomed. Anal. 2020, 193, 113707. [CrossRef]

43. Nageeb, A.; Al-Tawashi, A.; Mohammad Emwas, A.-H.; Abdel-Halim Al-Talla, Z.; Al-Rifai, N. Comparison of Artemisia Annua Bioactivities between Traditional Medicine and Chemical Extracts. Curr. Bioact. Compd. 2013, 9, 324-332. [CrossRef] [PubMed]

44. Ferreira, J.F.S.; Luthria, D.L.; Sasaki, T.; Heyerick, A. Flavonoids from Artemisia annua L. as Antioxidants and Their Potential Synergism with Artemisinin against Malaria and Cancer. Molecules 2010, 15, 3135-3170. [CrossRef]

45. Abbas, M.; Saeed, F.; Anjum, F.M.; Afzaal, M.; Tufail, T.; Bashir, M.S.; Ishtiaq, A.; Hussain, S.; Suleria, H.A.R. Natural Polyphenols: An Overview. Int. J. Food Prop. 2017, 20, 1689-1699. [CrossRef]

46. Dzah, C.S.; Duan, Y.; Zhang, H.; Serwah Boateng, N.A.; Ma, H. Latest Developments in Polyphenol Recovery and Purification from Plant By-Products: A Review. Trends Food Sci. Technol. 2020, 99, 375-388. [CrossRef]

47. Springob, K.; Kutchan, T.M. Introduction to the Different Classes of Natural Products. In Plant-Derived Natural Products; Osbourn, A.E., Lanzotti, V., Eds.; Springer: New York, NY, USA, 2009; pp. 3-50.

48. Batiha, G.E.S.; Olatunde, A.; El-Mleeh, A.; Hetta, H.F.; Al-Rejaie, S.; Alghamdi, S.; Zahoor, M.; Magdy Beshbishy, A.; Murata, T.; Zaragoza-Bastida, A.; et al. Bioactive compounds, pharmacological actions, and pharmacokinetics of wormwood (Artemisia absinthium). Antibiotics 2020, 9, 353. [CrossRef]

49. Kim, M.H.; Seo, J.Y.; Liu, K.H.; Kim, J.S. Protective effect of Artemisia annua L. extract against galactose-induced oxidative stress in mice. PLoS ONE 2014, 9, e101486. [CrossRef]

50. Barnabei, L.; Laplantine, E.; Mbongo, W.; Rieux-Laucat, F.; Weil, R. NF-kB: At the Borders of Autoimmunity and Inflammation. Front. Immunol. 2021, 12, 3169. [CrossRef]

51. Foglio, M.A.; Dias, P.C.; Antônio, M.A.; Possenti, A.; Rodrigues, R.A.F.; da Silva, É.F.; Rehder, V.L.G.; de Carvalho, J.E. Antiulcerogenic Activity of Some Sesquiterpene Lactones Isolated from Artemisia Annua. Planta Med. 2002, 68, 515-518. [CrossRef] [PubMed]

52. Su, X.Z.; Miller, L.H. The discovery of artemisinin and the Nobel Prize in Physiology or Medicine. Sci. China Life Sci. 2015, 58, 1175-1179. [CrossRef] [PubMed]

53. Von Hagens, C.; Walter-Sack, I.; Goeckenjan, M.; Osburg, J.; Storch-Hagenlocher, B.; Sertel, S. Prospective open uncontrolled phase I study to define a welltolerated dose of oral artesunate as add-on therapy in patients with metastatic breast cancer (ARTIC M33/2). Breast Cancer Res. Treat. 2017, 164, 359-369. [CrossRef] [PubMed]

54. Zhang, B.; Liu, P.; Zhou, Y.; Chen, Z.; He, Y.; Mo, M. Dihydroartemisinin attenuates renal fibrosis through regulation of fibroblast proliferation and differentiation. Life Sci. 2019, 223, 29-37. [CrossRef]

55. Sharma, B.N.; Marschall, M.; Henriksen, S.; Rinaldo, C.H. Antiviral effects of artesunate on polyomavirus BK replication in primary human kidney cells. Antimicrob. Agents Chemother. 2014, 58, 279-289. [CrossRef]

56. Xia, M.; Liu, D.; Liu, Y.; Liu, H. The therapeutic effect of artemisinin and its derivatives in kidney disease. Front. Pharmacol. 2020, 11, 380. [CrossRef]

57. O'neill, P.M.; Barton, V.E.; Ward, S.A. The molecular mechanism of action of artemisinin-The debate continues. Molecules 2010, 15, 1705-1721. [CrossRef]

58. Dong, Y.; Wittlin, S.; Sriraghavan, K.; Chollet, J.; Charman, S.A.; Charman, W.N.; Scheurer, C.; Urwyler, H.; Santo Tomas, J.; Snyder, C.; et al. The structure-activity relationship of the antimalarial ozonide Arterolane (OZ277). J. Med. Chem. 2010, 53, 481-491. [CrossRef] 